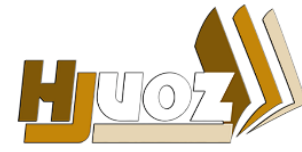

hjuoz.uoz.edu.krd p-ISSN: 2410-7557
كَوّارا زانستيّن مروّقايهتى يا زانكوّيا زاخوّ

مجلة العلوم الانسانية لجامعة زاخو

Humanities Journal of University of Zakho (HJUOZ)

Vol. 4, No. 3, pp. 491-507, December-2016

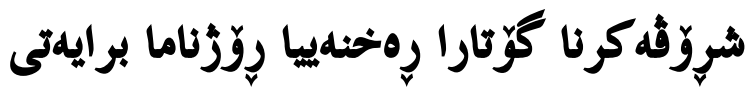 (لدويف يِّكهيّنهيّن جفاكناسى - واتاييّن قهل ليوّن)ى
}

\author{
عبدالسلام نجم الدين عبدالله و حسين عثمان عبدالرحمن

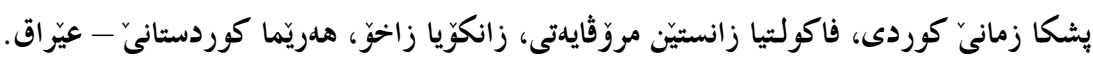 \\ https://doi.org/10.26436/2016.4.3.285
}

كورتيا ليَكولينىّ:

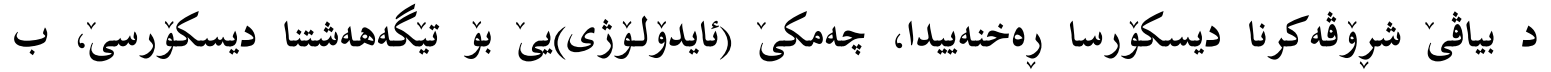

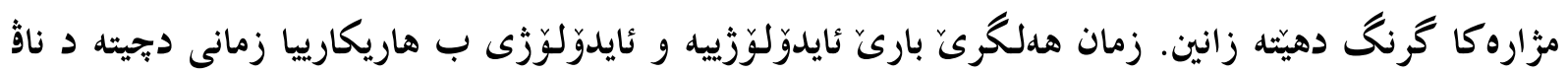

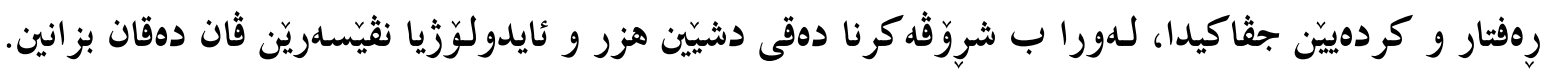

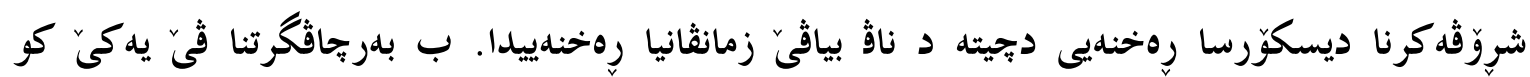

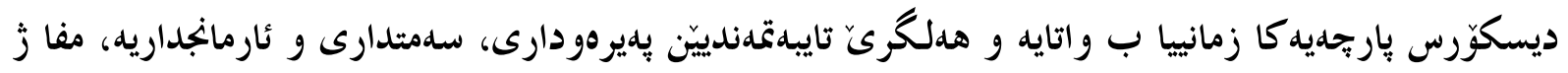

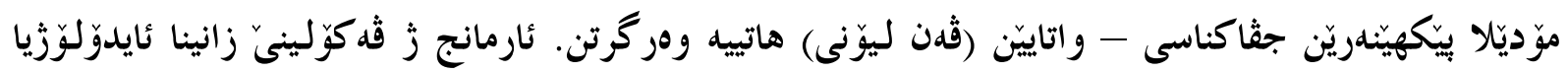

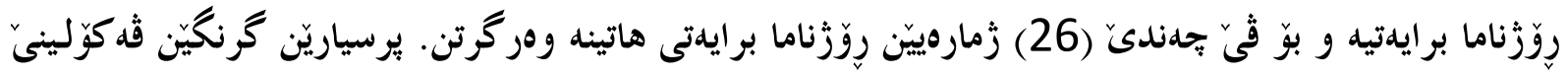

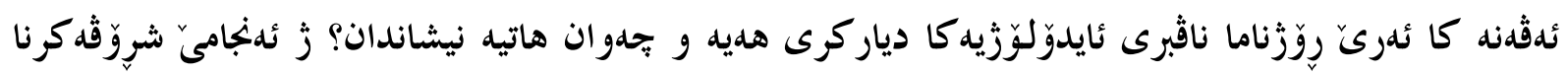

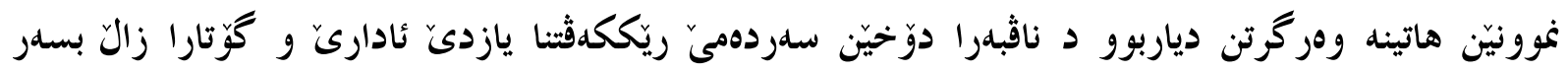

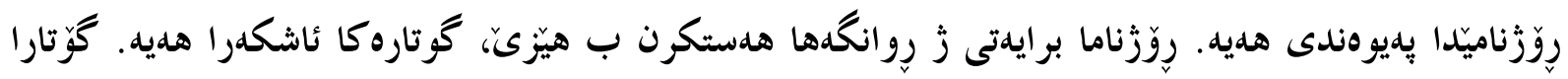

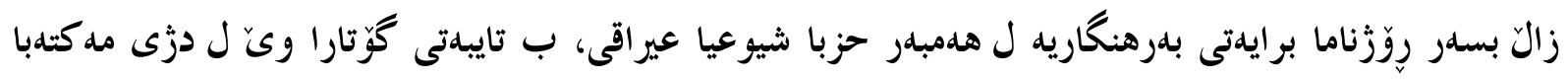

$$
\text { مهر كهزيا قَى حزبيّيه. }
$$

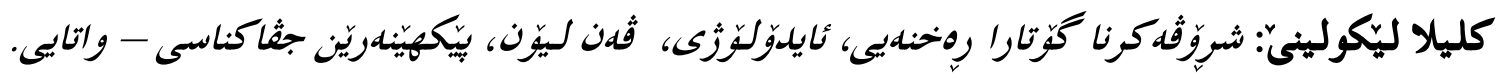

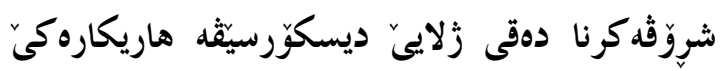

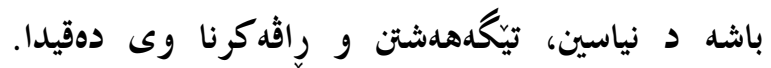

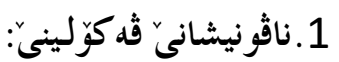

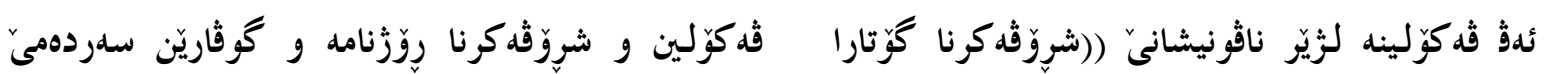

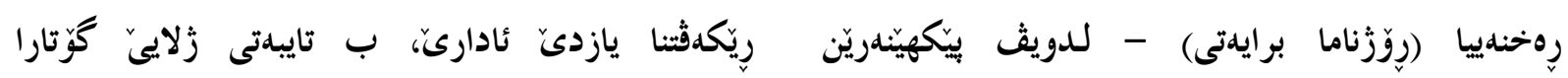

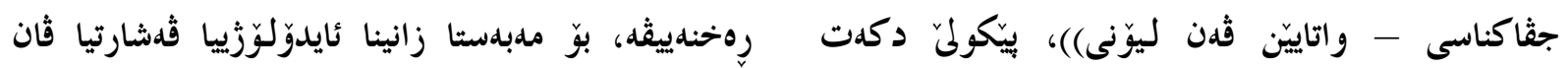

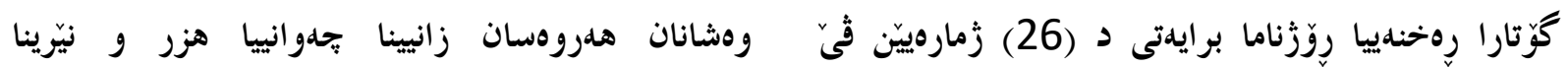

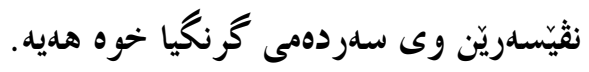

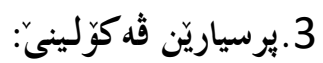

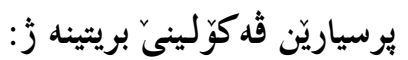


سهر ب قوتابخانا (براخى)ى بوو و ز لايى ( فرب)ى كو

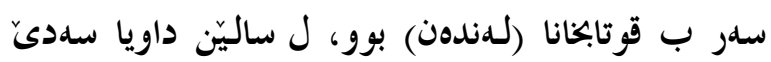
بوورى زى (هاليداى و روقديا حهسهن)ى قدكوّلين ل

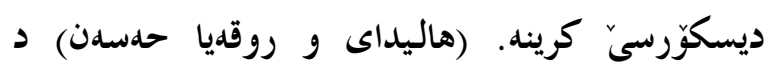

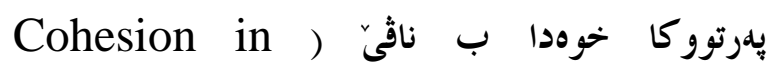

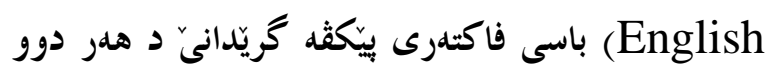

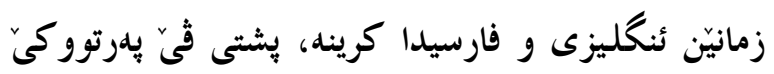

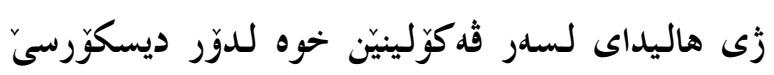

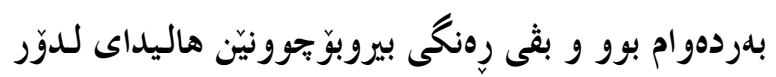

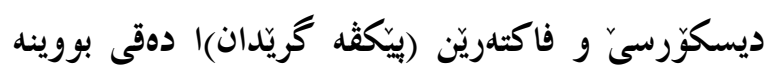

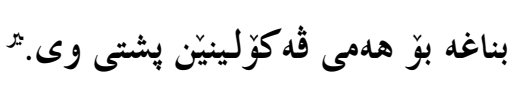

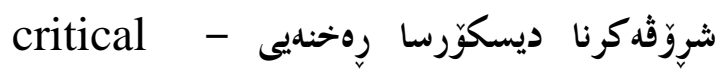
لdiscourse analysis

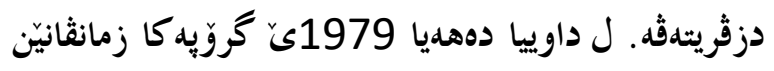

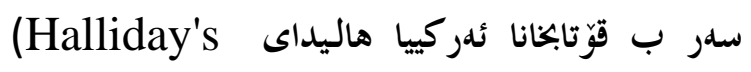
- functional linguistics)

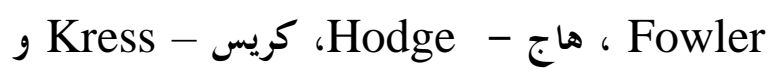

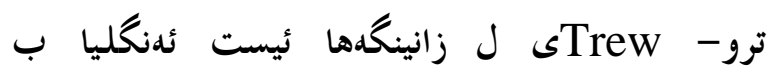

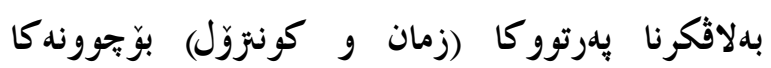

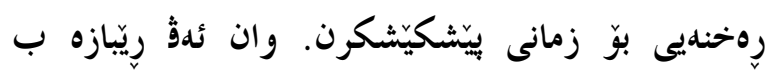

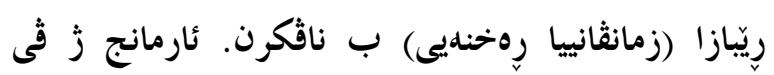

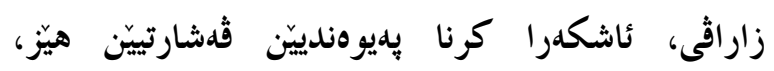

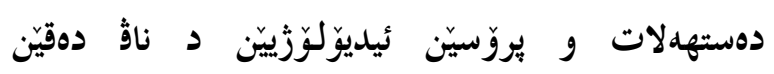
زمانيدايه. زمانفانيّ رهخنهيى خوه ز زمانفانييا وهسفى جوَدا

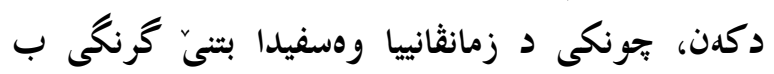

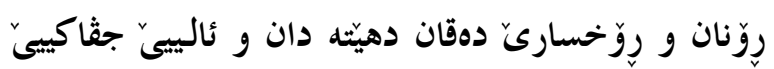

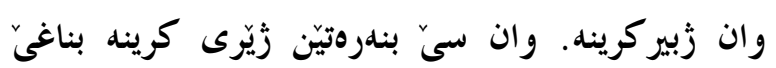
كارى خوه:

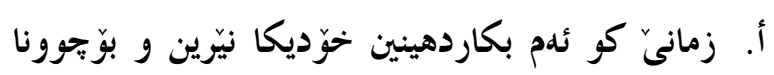

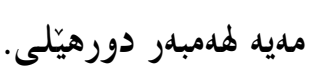

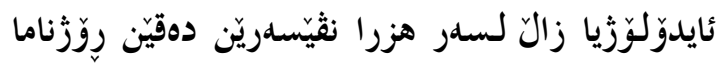
برايدتيدا تحهوان هاتيه فه كوهاستن؟

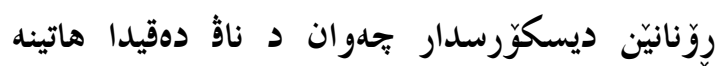

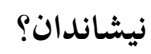

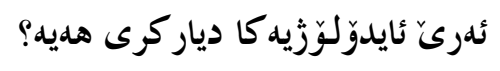

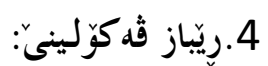

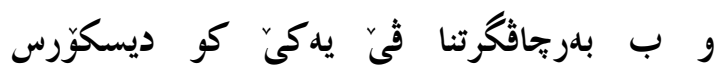

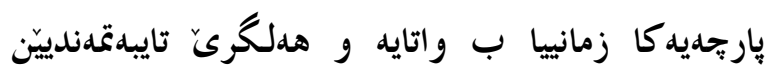

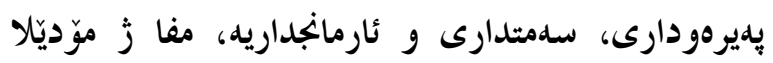

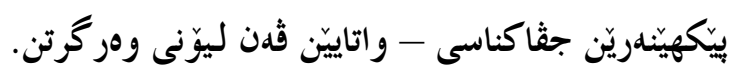

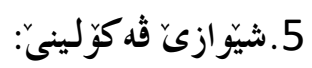

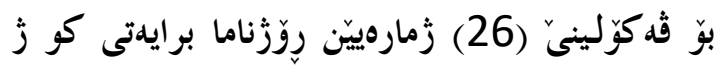

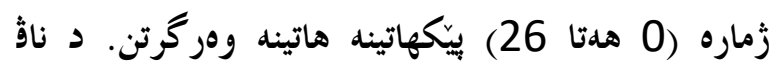

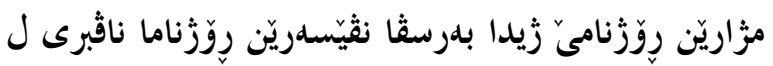

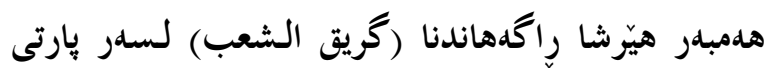

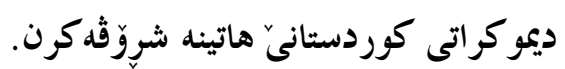

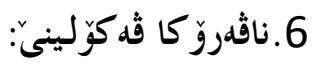

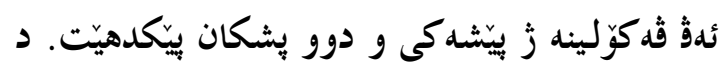

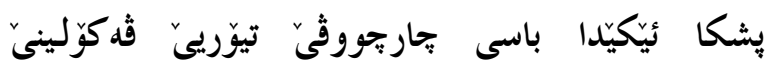

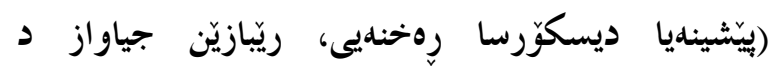

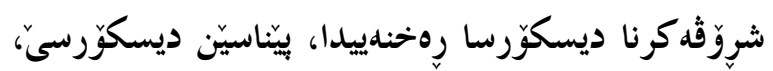

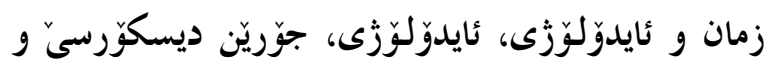

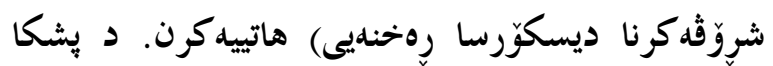

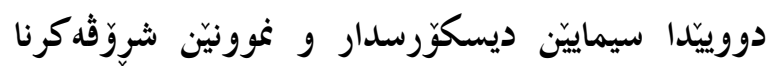
كوّتاريّن رِوَّزناما برايدتى هاتينه باسكرن.

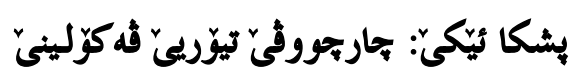

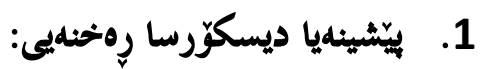

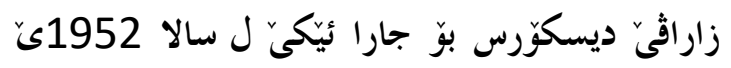

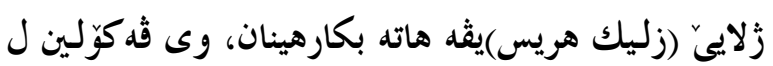

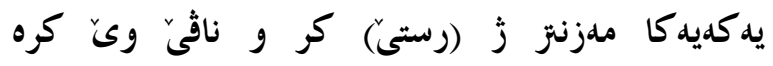

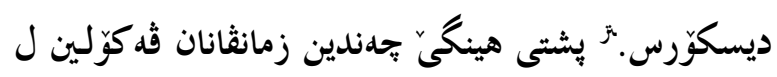

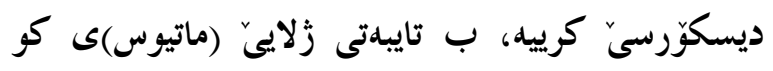




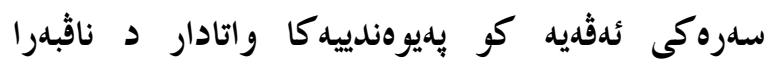

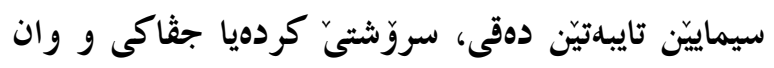

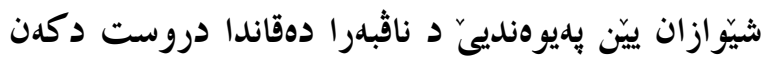
و راقه د كهن، هدئ.

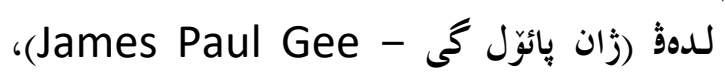

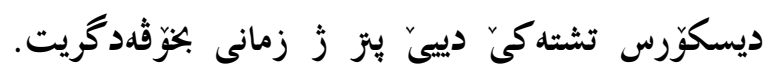

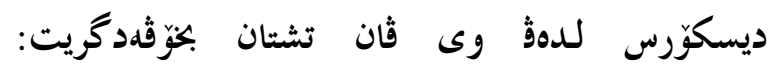

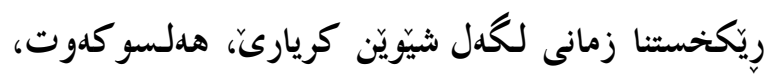

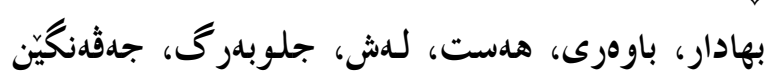
نهزمانى، تشت، كهرهسته، ته كنولّوزَى، زمان و و جه.

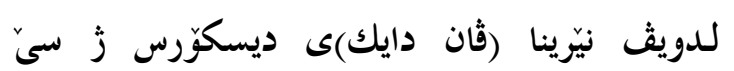

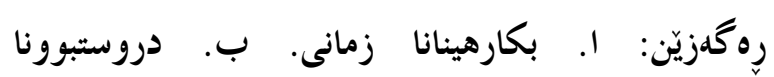

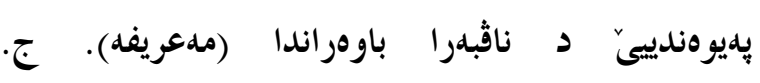
هدلسو كهوت د هدلكهوثتينّ جثاكيدا بيّك دهيَت. (فريّكلاف) ديسكوّرسيَ د سئ واتاييّن جياوازدا

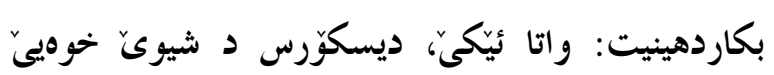

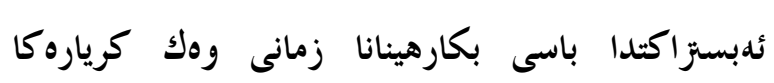

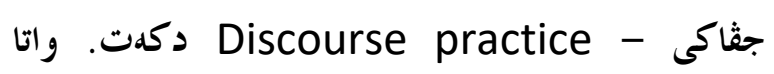

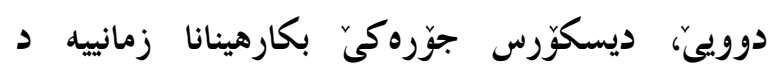

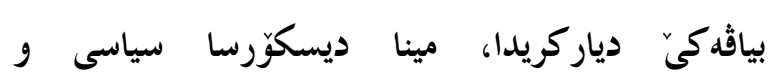

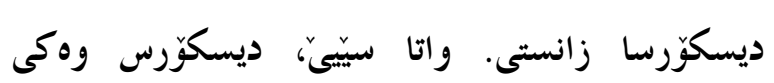

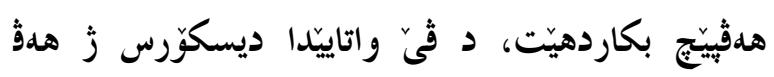
دهيّنه جوداكرن.

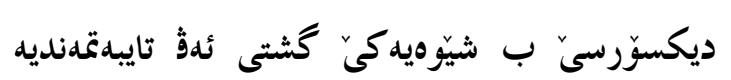

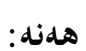
1.هدر ديسكوّرسهك دشيّت دابهشى دوو يان بحهند ديسكوَرسيّن دى ببيت. 2.دوو يان بجهند ديسكوّرس دشيّن د دئكَ ديسكوّرسدا

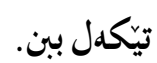

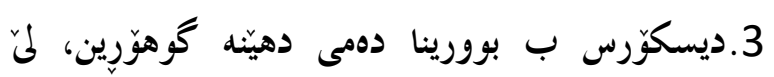
هيّليّن سهرهكى د ناقبهرا واندا هدر دمينن.

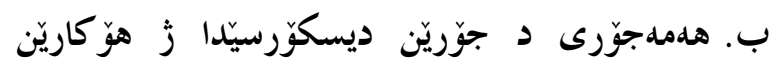
ئابوورى و جثاكى ناهيّته جوّداكرن. لدوروا هلمهوجّرييا زمانى قهزَهنا جياوازييّن جثاكييه.

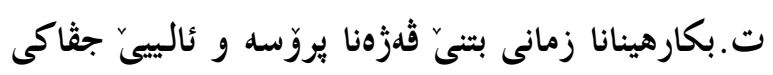

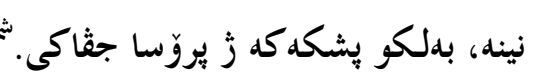

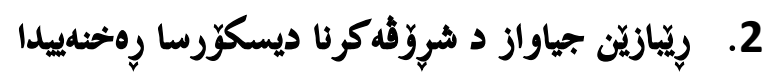

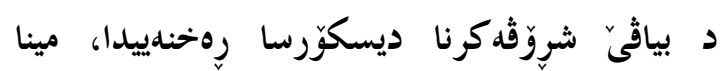

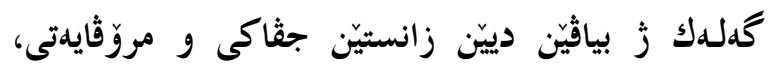

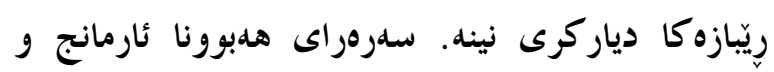

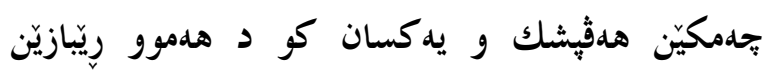

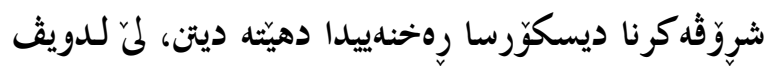

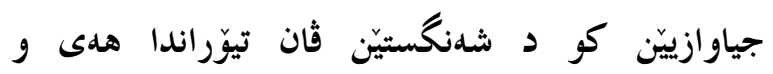

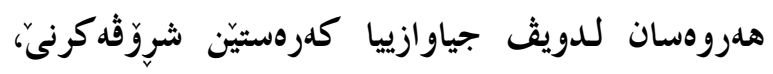

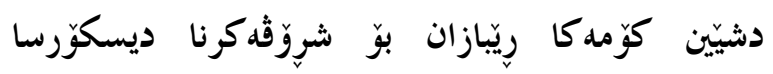

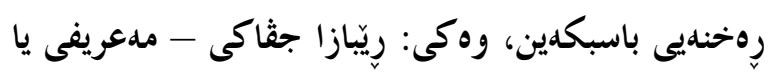

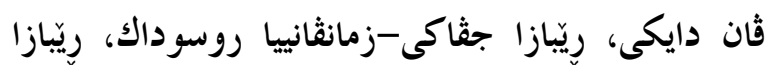

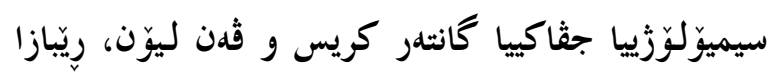

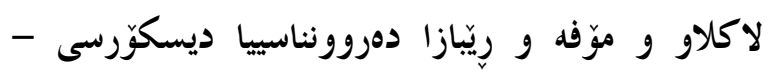
discourse-psychology قَى قُكوَلينيّدا مه رِيّبازا (قُهن ليوّنى) بكارهينايه. 3. بيّاسيّن ديسكوّرسيَ

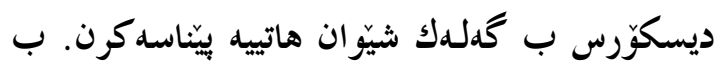
كورتى، ههر وهكى (ئستوّبز) دبيّزَيت: ديسكوّرس

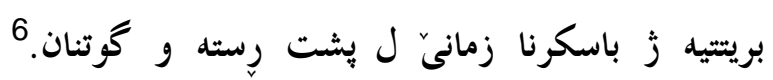

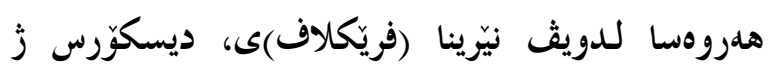

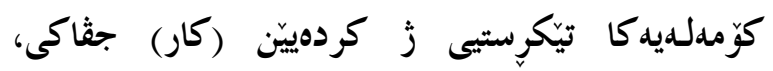
كرياريّن ديسكوّرسى (بهرهممهينان، دابهشكرو مهزاختنا

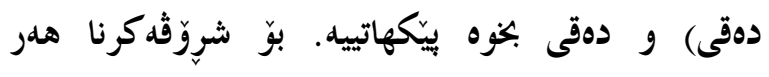

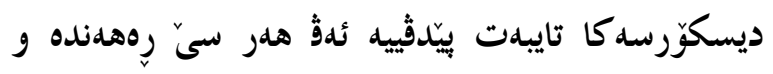

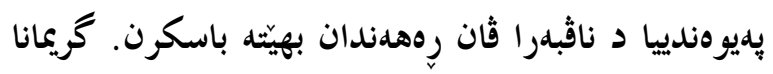


دروسبوونا بِديوهنديى د ناقبهرا باوهران و هلفسهنكى د بوَّنهيّن جثاكيدا.

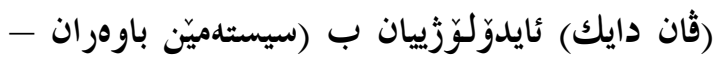
(systems of believes جفاكى - مهعريفى - socio - cognitive يا ويدا،

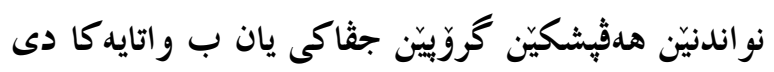

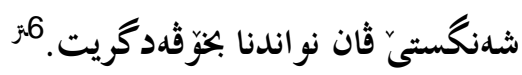

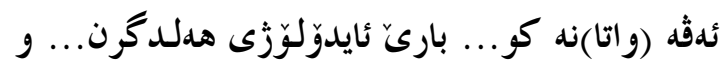

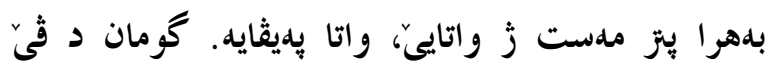

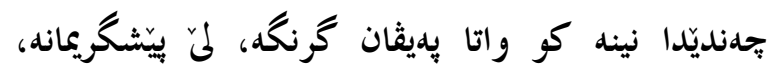

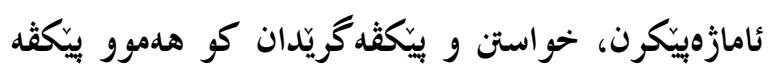

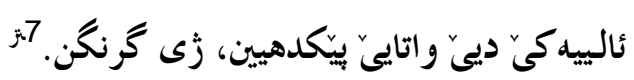

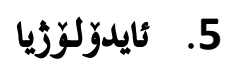
لدويث نيرّينا (فريككلاف)، ئايدوّلوَّرى بريتيه ز

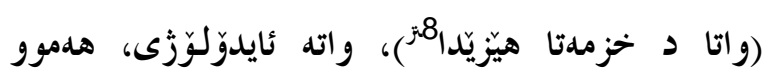

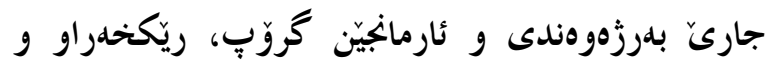

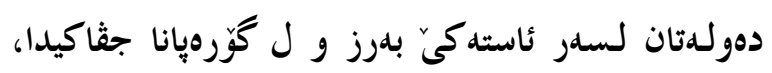

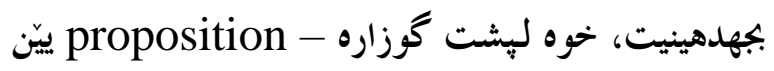

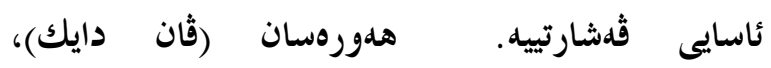

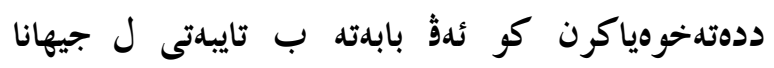

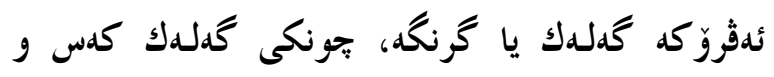

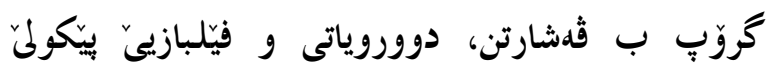

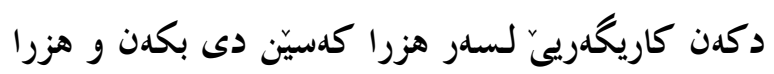

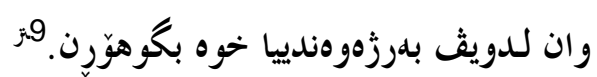

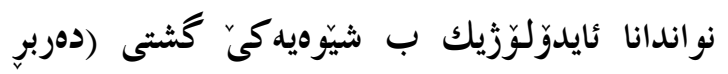

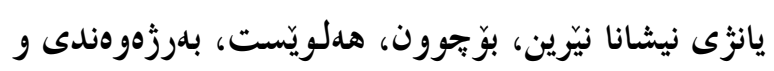

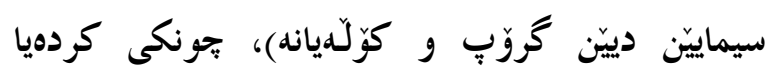

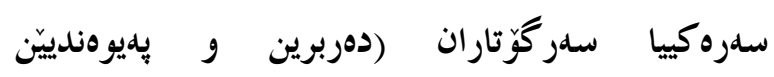

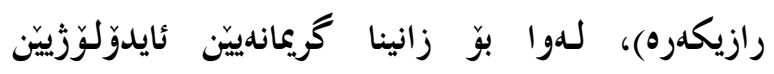

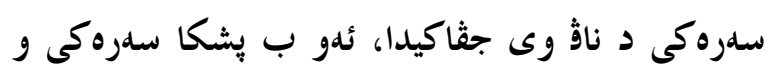
كرنق د دوقدا دهيَّه هزَمارتن.
4. ديسكوّرسيّن نوى بِهيدا دبن، و ديسكوّرسيّن كثن دمرن. 5.ديسكوّرس هلموو جاريّ تلدواوكهر يان لدرّى

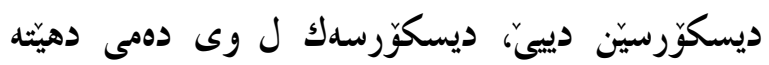

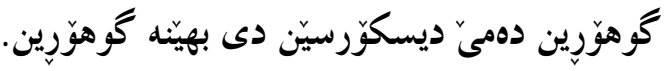

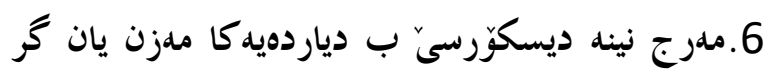

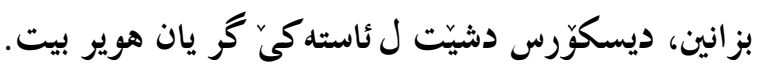

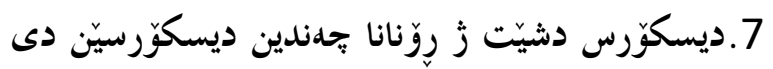

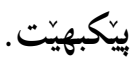

8. حهندين جوَريّن ديسكورّان هدنه و جَ ريّك نين كو

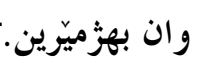
4.

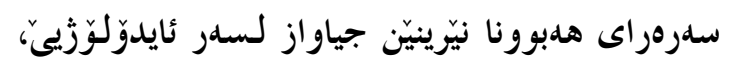

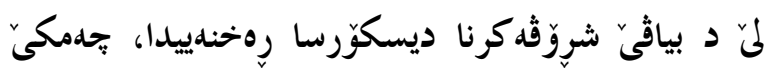

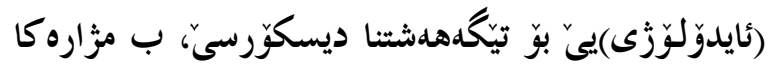

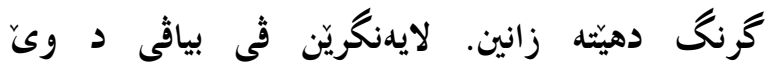

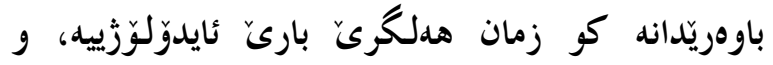

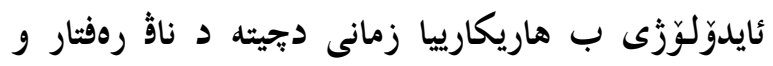

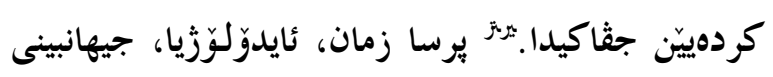

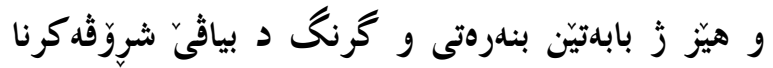

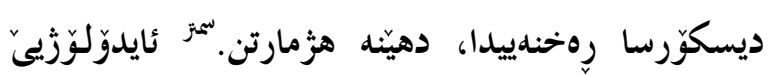

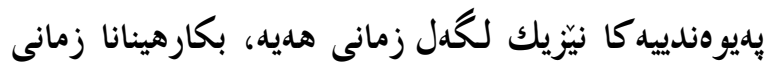

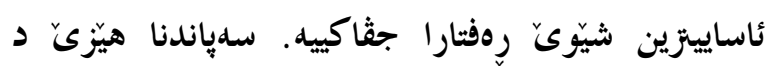

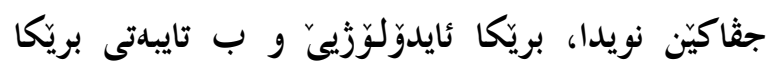

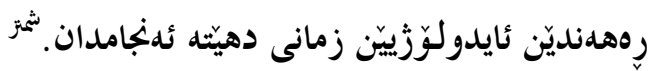

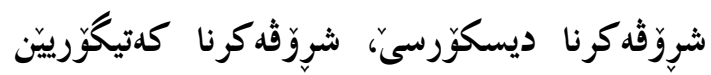

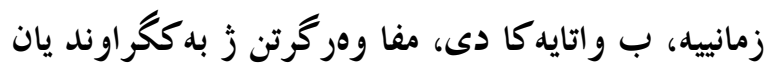

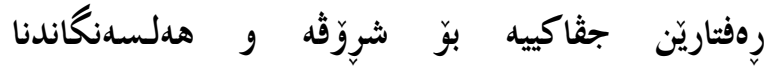

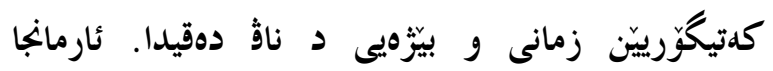

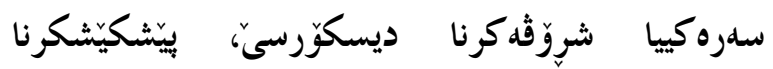

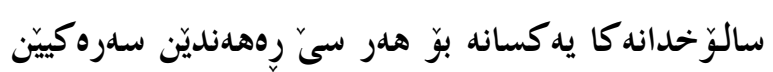

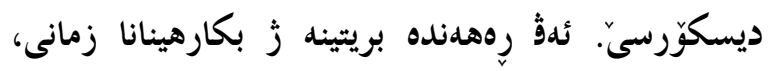




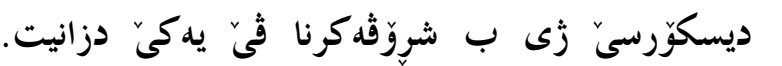

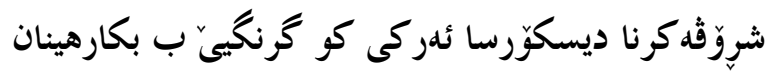

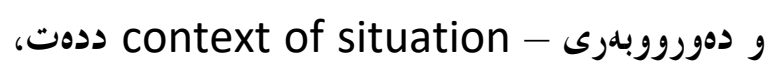

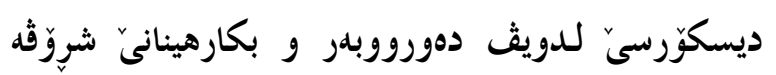

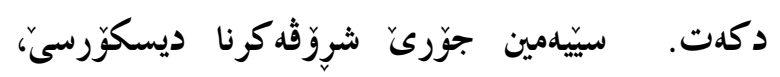

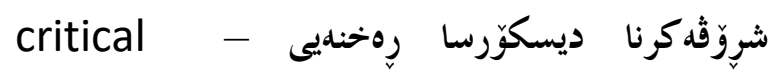
discourse analysis

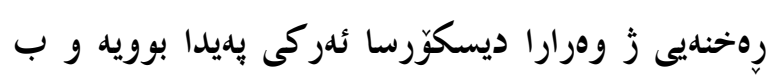

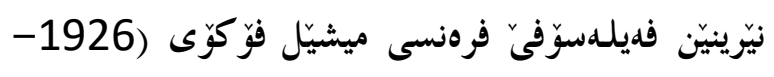

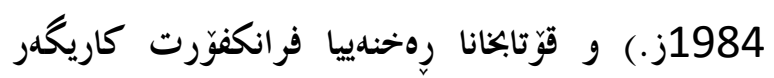
بوريه.

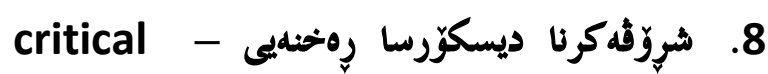
discourse analysis

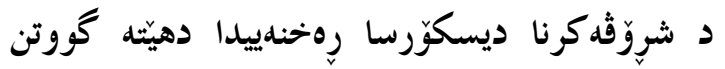

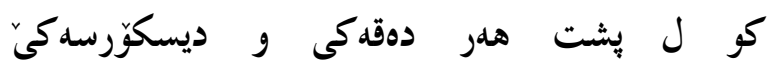

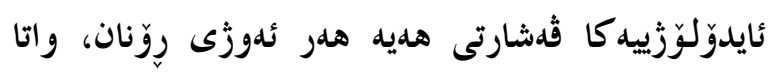

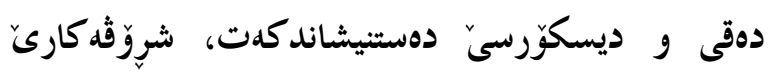

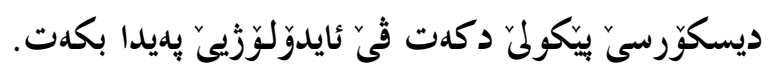

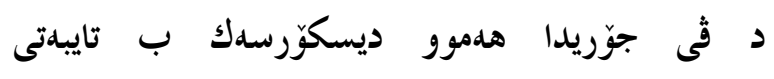

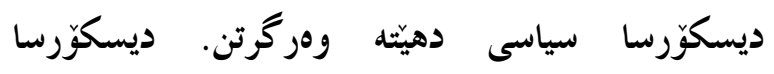

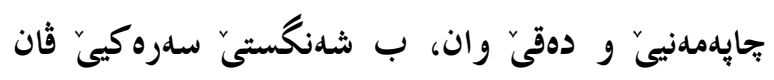

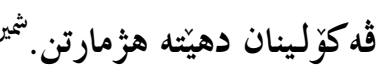

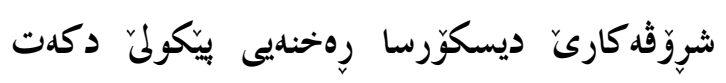

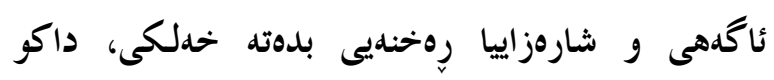

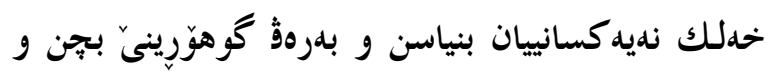

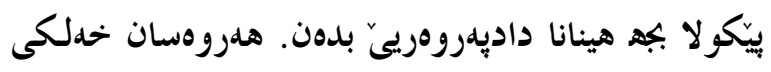

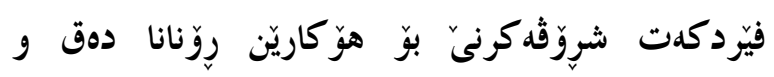

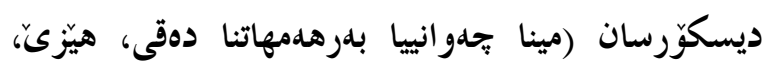

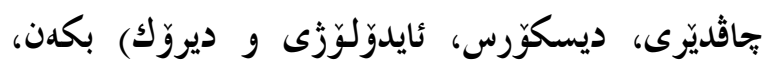
داكو باشتز راستييان بزان.

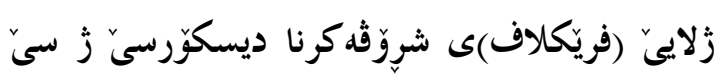

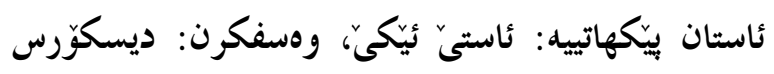

discursive - روّنانيّن ديسكوّرسى Structures

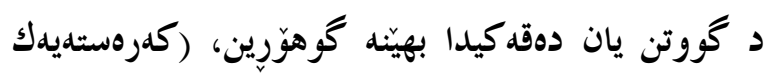

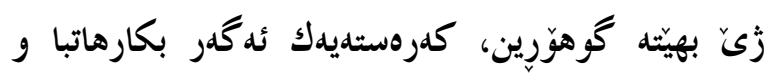

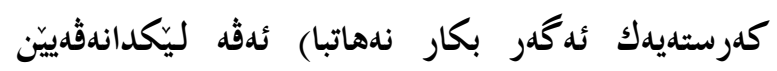

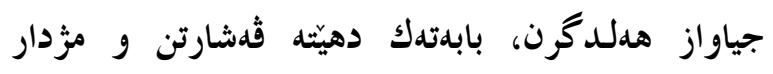

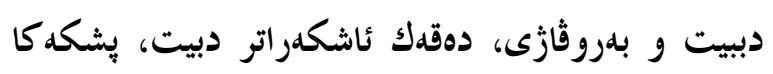

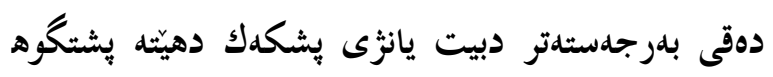

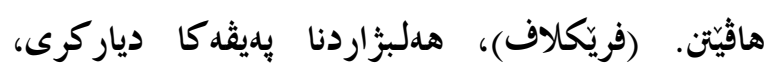

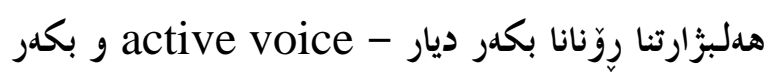

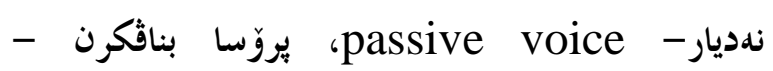
nominalization

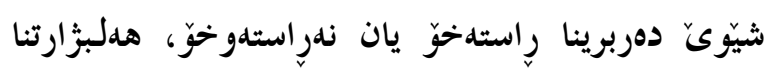

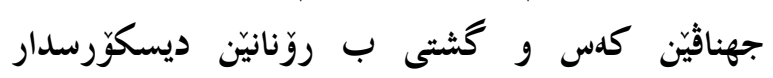
دزانيت. . 6

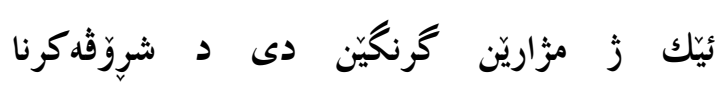

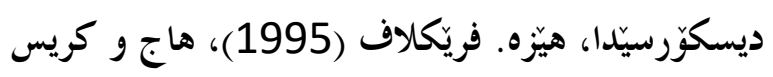

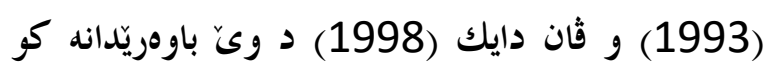

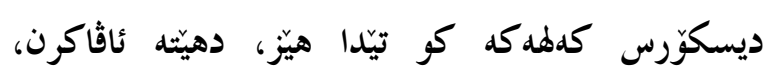

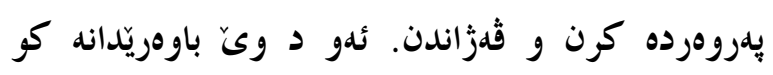

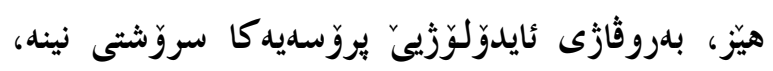

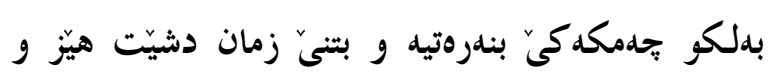

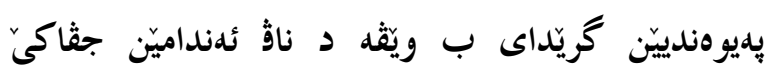
ديار كريدا ويَنابكهت 7. جوّريّن ديسكوّرسيَ

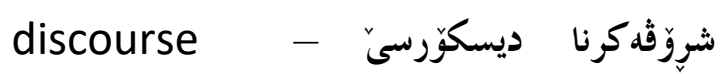
analysis

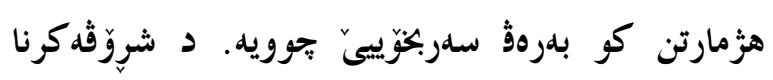

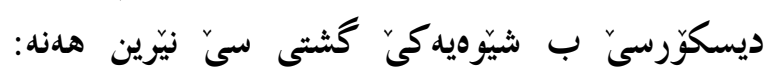

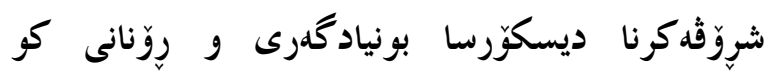

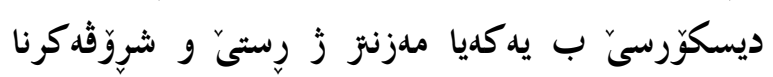




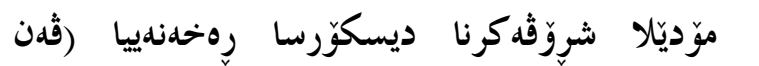

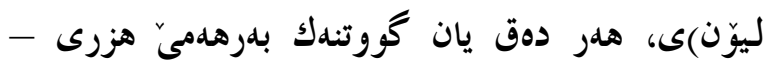

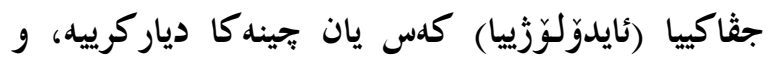

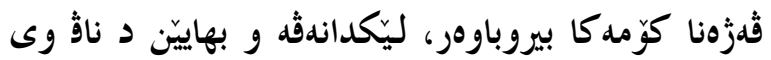

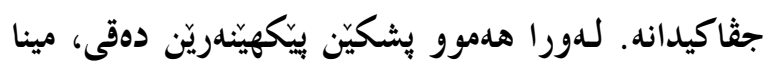

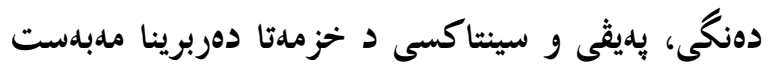

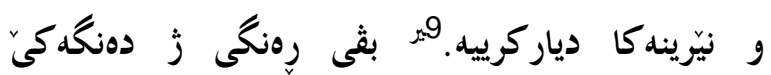
دياركرى هلتا دهقدكى دياركرى، دشيّن مينا سيماييّن ديسكوّرسدار بهيّنه وهرگرَتن.

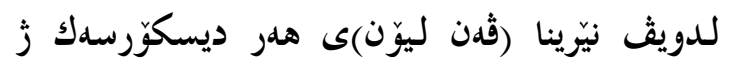
كوّمهكا سيماييّن ديسكوّرسدار بيّكهاتييه. بِيَّكهاتيّن

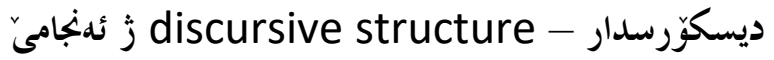

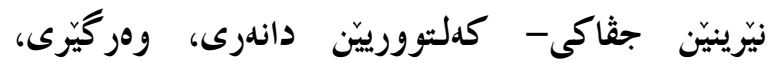

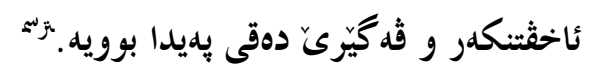

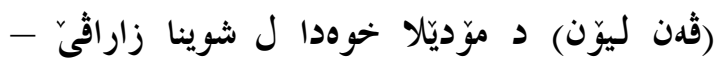

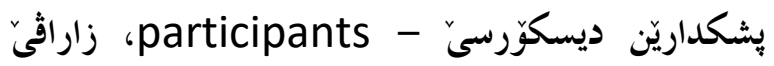
بكاريّن جثاكى - social actor بكاردين

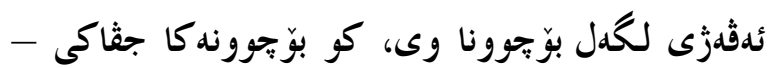
واتايى - social semantic هديه دگكونجيت.

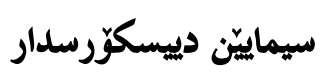

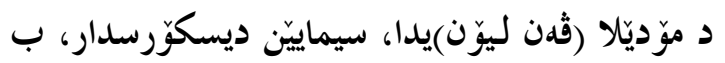
سهر دوو جوَران هاتينه دابهشكرن، سيماييّن لسهر بنهرهتى قهشارتنى - covertness و سيماييّن لسهر بنهرهتى ئاشكهرايى - Overtness دهيّن. ئهة سيمايه لدويث ملبهستا دانهرى، هلرووسان لدويث بحهوانييا هزركرنا هزرى - جثاكييا دانهرى و زَ بيّخحمدات

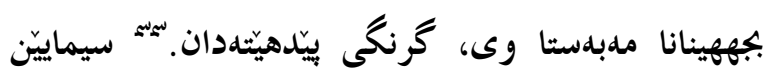

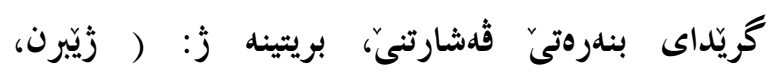

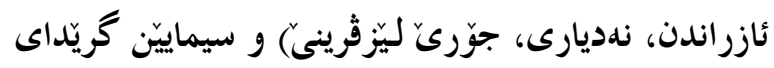

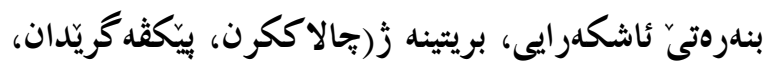
زيكّة كرن، بنافكرن)

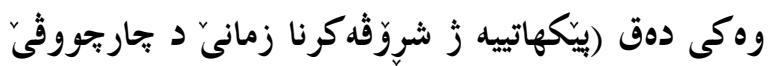

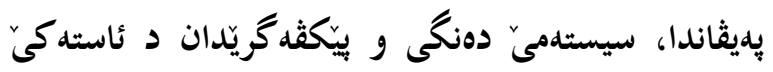

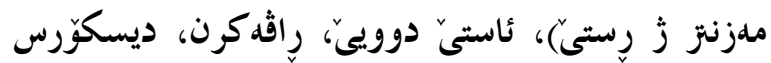

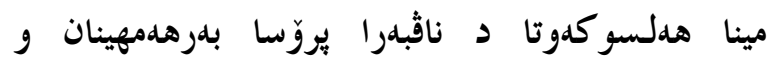

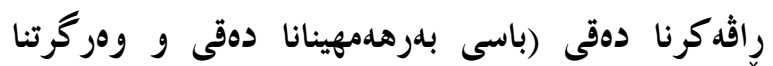

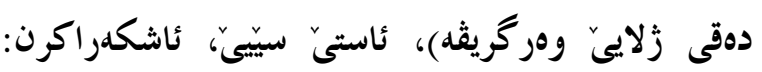

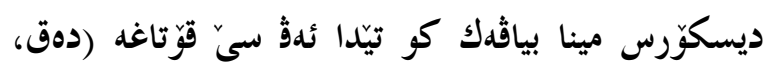

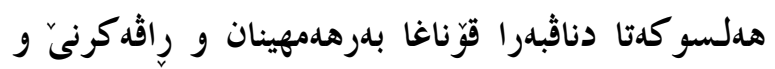

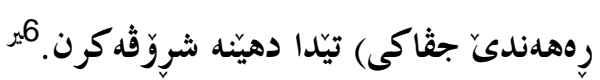
ويّداك - wodak و لودويگ - Ludwig

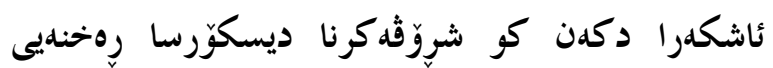

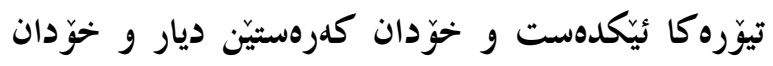

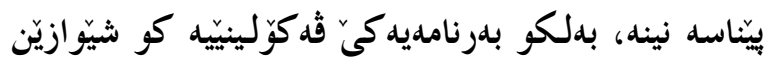

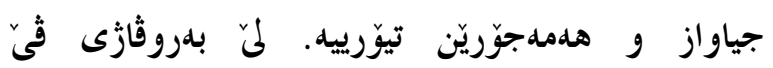

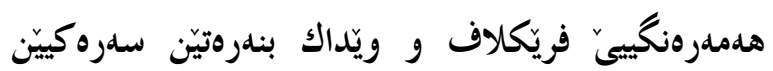

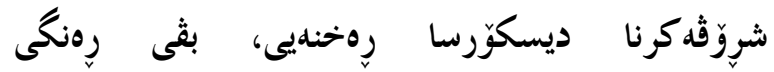
دهستنيشاند كهن.]

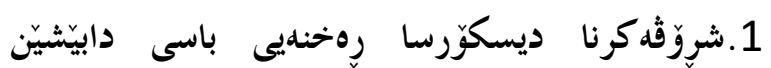
جقاكى دكهت 2. يهيوهندييّن هيّزى، ديسكوّر دينه.

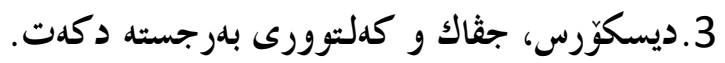
4. ديسكوّرسىّ، كردهيه كا ئايدوَّلَّزَّى هديه.

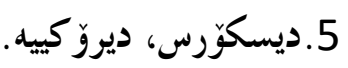

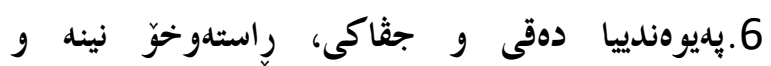
كهدينهروك هديه.

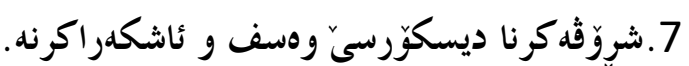
8. ديسكوّرس شيوهيهكى دييى كردوريا جثاكييه.

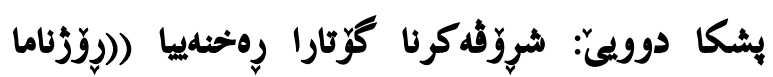

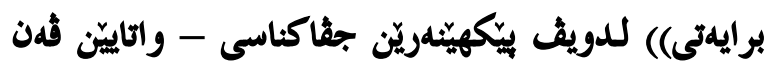
ليون) ليونى van leeuwen - قهن ليون 


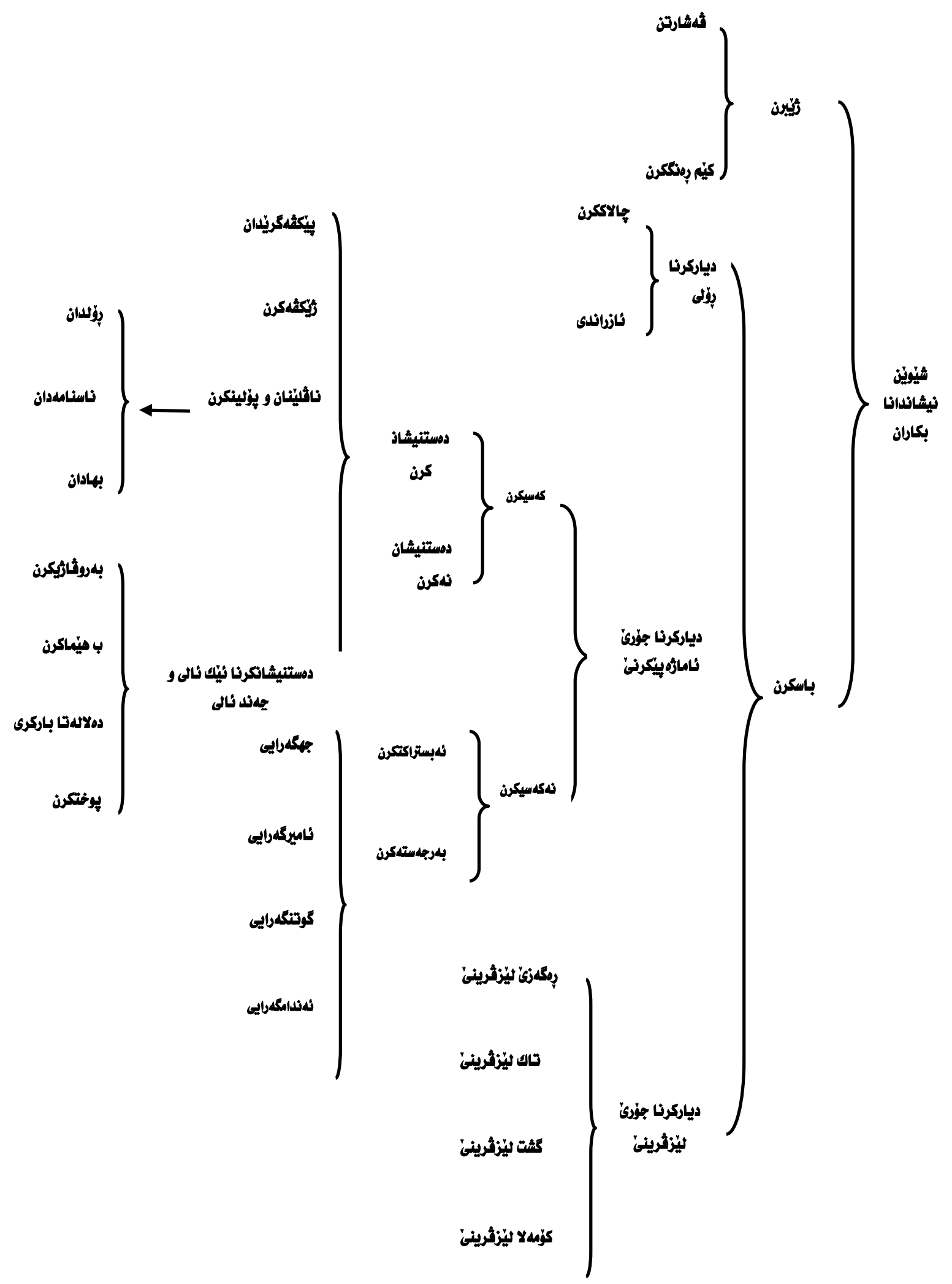


سنكى بوّ ئهو مافانه بكاتهوه... . ()) (روّرَّامهى برايدتى:

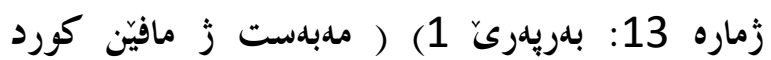
نههاتيه دياركرن كا كيز مافن. )

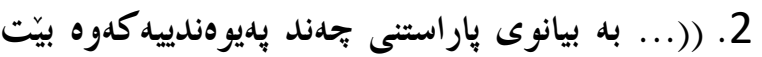

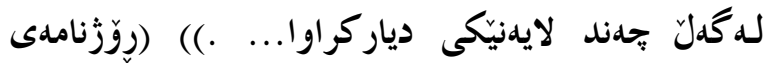
برايدتى: زماره 13: بلريهريّ 7) ( ئدة لايهنه نههايتنه دياركرن (ئن 3. ((خوّ ئه گهر كَّرِينيّك له سياسهتيانا رووى داوه دهبا

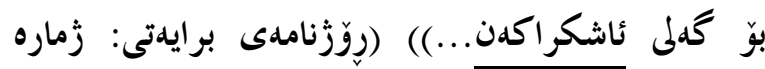

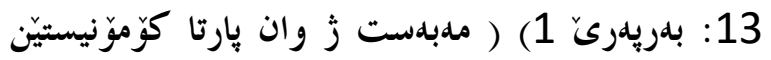
عيّر اقيّيه. . ) 4. باسى ديمو كر اتيهت بكات له باريحليهكى ئهم عيّر اقه

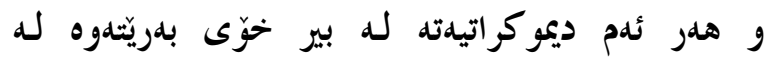

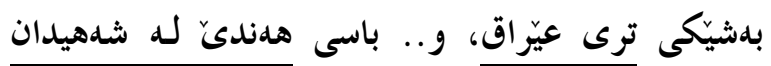

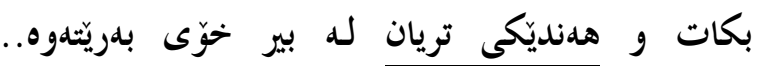

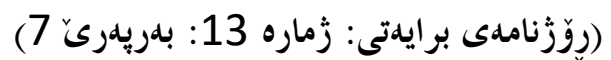
(ملبهست زيى عهرهب و شههيديّن عهرهب و كوردستان و شههيديّن كوردستانيّيه.)

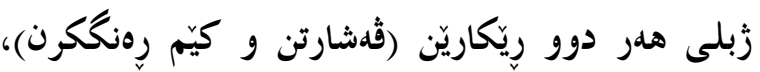

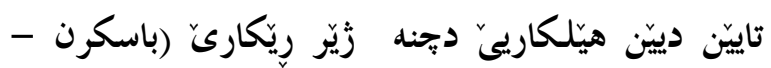
inclusion

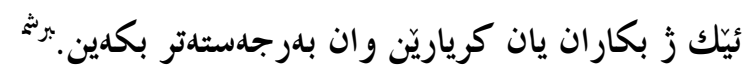
2.

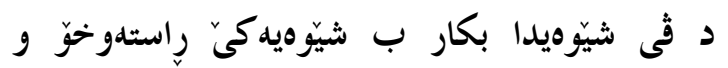

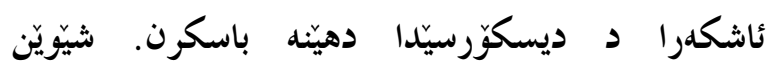

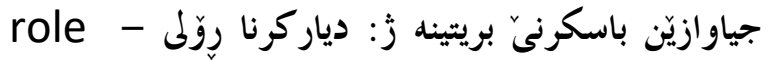
- allocation

$$
\text { 1 }
$$

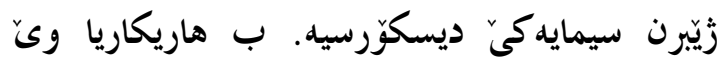

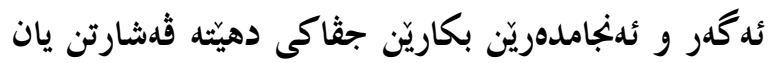

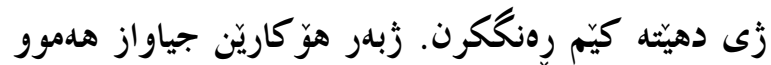

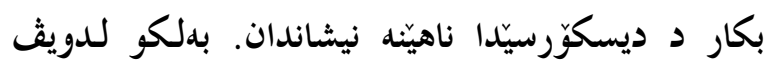
ئارمانجا بهرهدمهينهريّن ديسكوّرسى دهردكةقيت يان كيّم

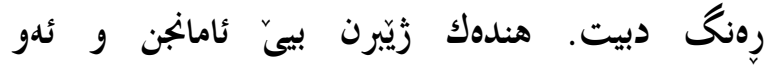
هوير كارينه ييّن وهرگر ئاكدهدارى وانه يان زيى نههاتنا

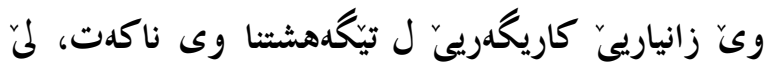

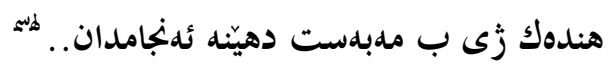
suppression - زَيّبرن ب دوو ريكيّن (ڤهشارتن

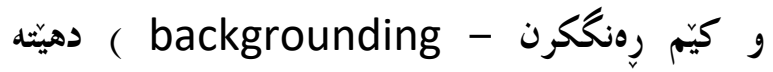

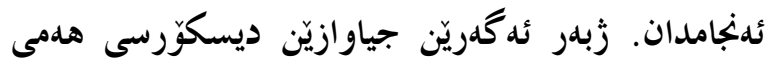
بكاريّن جثاكى د ناة ديسكوّرسيّدا دهرناكدثن. هندهك

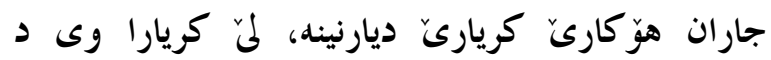

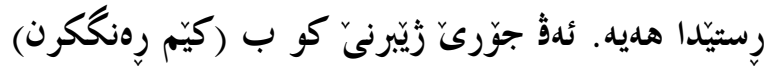

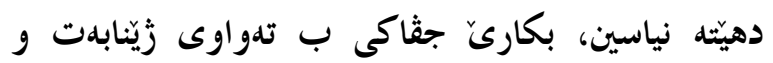

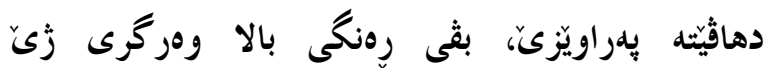

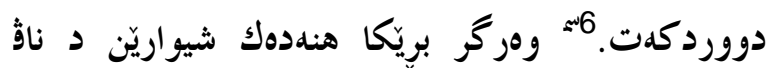

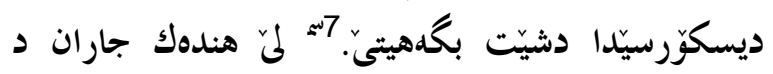

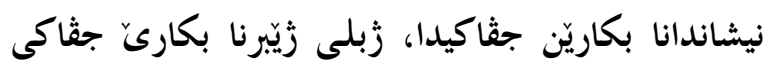

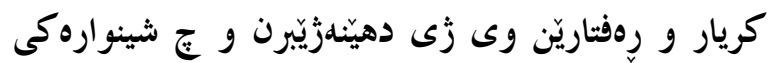

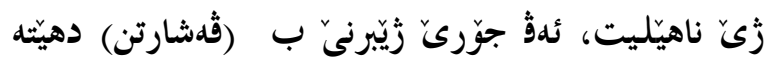

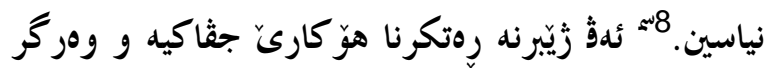

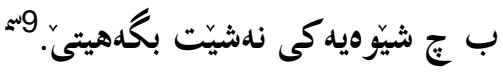

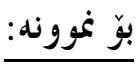
1. ((بلوه نابى كه حيزبى ناوبراو هدولى كدمكردنهوهى

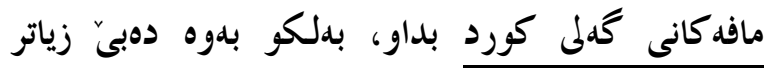




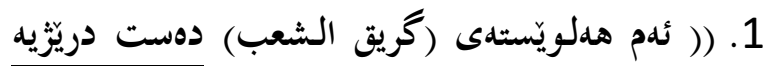

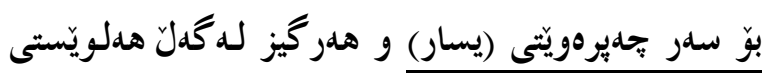

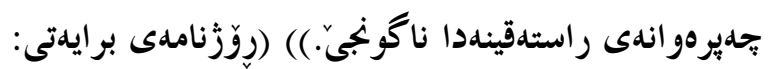
زماره 14: بلمربهرين 2. ((... ديكتاتوريّتى تاكرهوى قاسم كهدوته بهرياكردنى دهست دريّزى بوّ سهر بزوتنهوهى نيشتمانى كورد...())

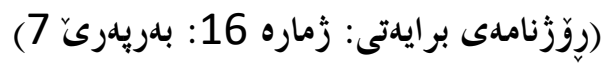

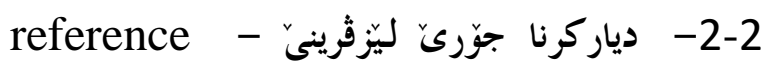
allocation

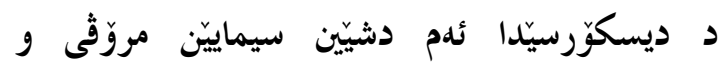

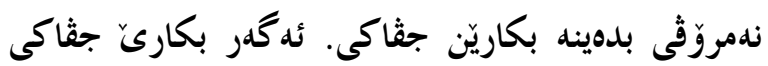

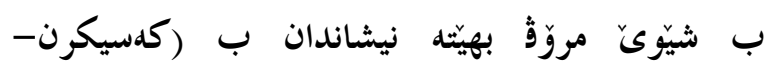
(personalization

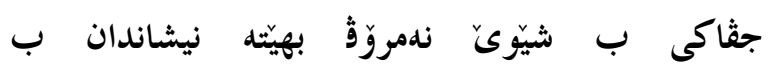

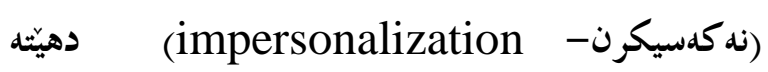

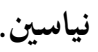

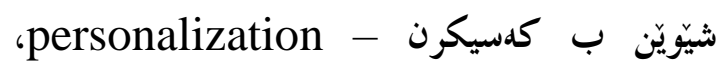

$$
\text { كهتيكوّرييّن ب كهسيكرن بريتينه زَ: }
$$

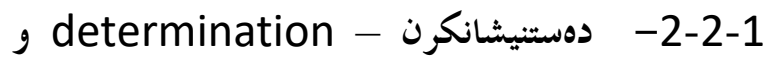
indetermination - دهسيشان نه كرن ئه گدر لدهمى نيشاندانا بكاريّن جثاكى، ناسناما وان ئاشكهرا و ديار بيت، مفا ز شيّوى (دهستنيشانكرن (determination بكاريّن جثاكى وهكى كهد وگروَبيّن نهنياس هاتبنه

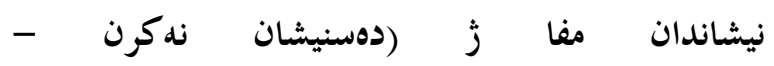
هاتيه وهر گرتن. (مفا وهزرتن (indetermination

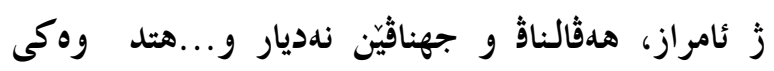

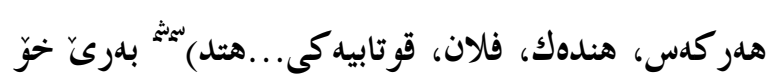
بدهنه بحهند نموونهيان ز دهسنيشان نهكرنىّ:

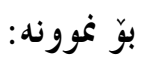

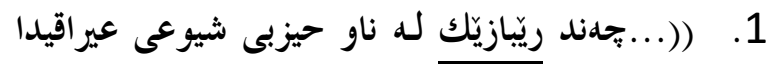

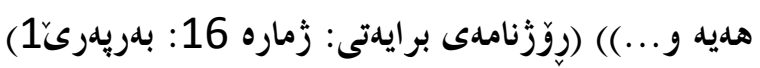

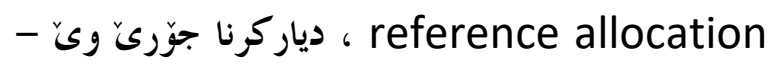
.type allocation role allocation - 2-1

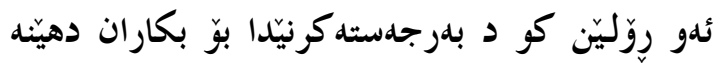
دان، واته دياركرنا بكهرى - agent و ئهو كهسى ئهو

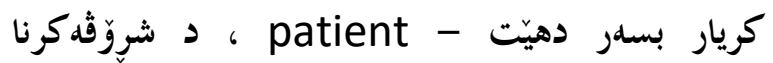

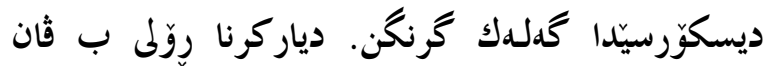

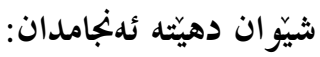

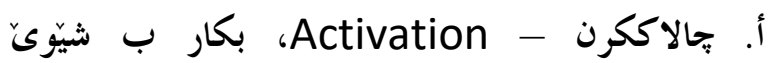

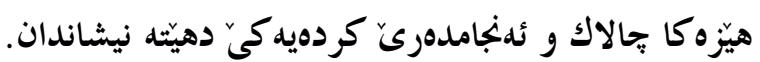
بوَّ نموونه:

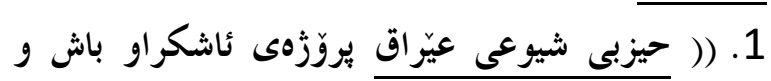

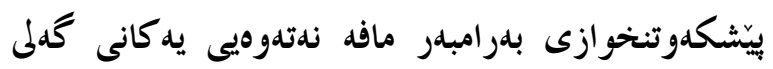

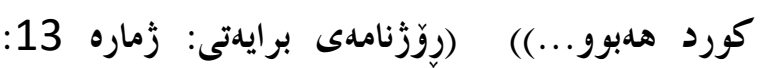

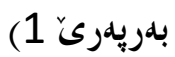

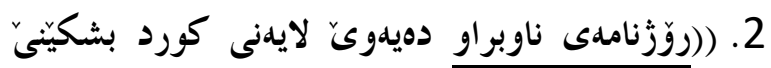

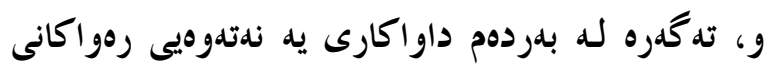

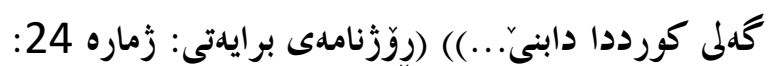

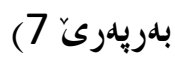

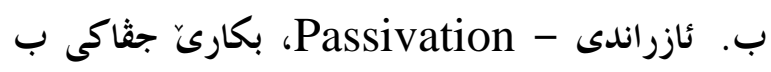

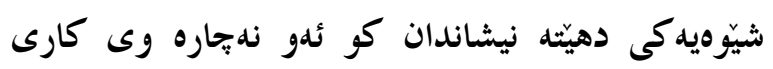

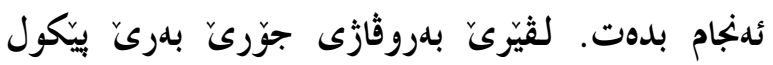

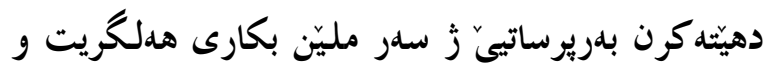

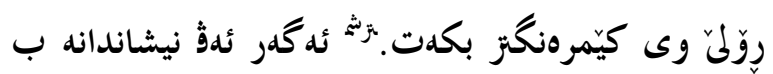
شيّوهيدكى بيت كو بكار ببيته مزٔار و بأرمانجا كرياريّ،

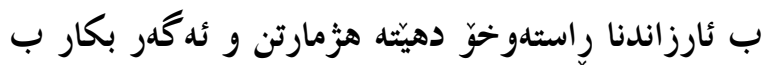

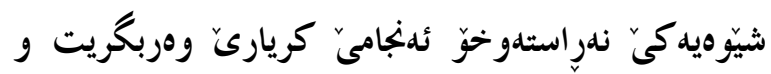

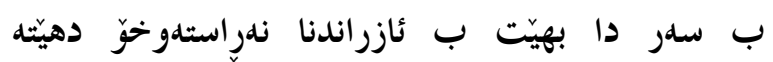

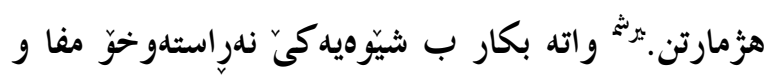
زيانيّن كريارىّ ب سهر دا دهيّن.

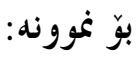


جوداكرنه بريّكا زمانى پِيدا نابيت و بريّكا واتايى دبيت.

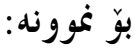
1

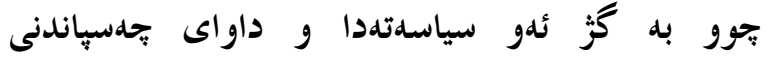
يديوهندى حيزبى شيوعى و شورشى كوردستانى ده كرد...)) (روّرَنامهى برايدتى: زماره 18: بهريهريّ

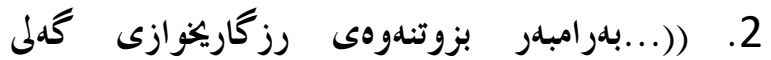

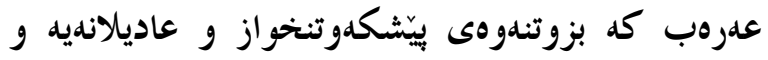

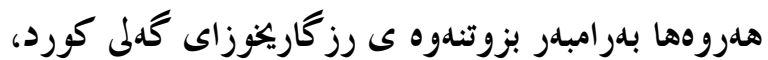

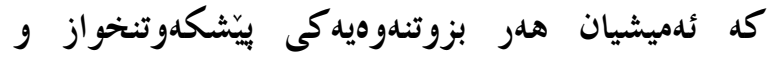
عاديلانديه.)) (روّرَّامهى برايدتى: زُماره 18: بلهريهرى

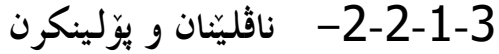
ئهكَر بكاريّن جثاكى د ديسكوّرسه كيّدا للدويث

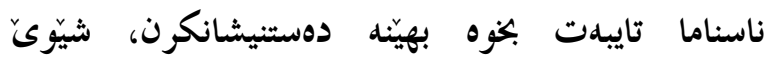

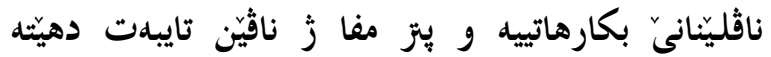

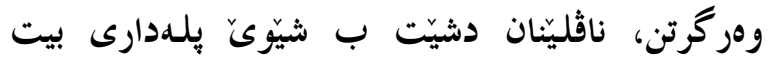

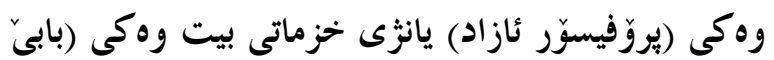

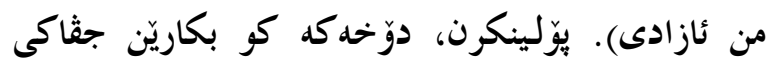

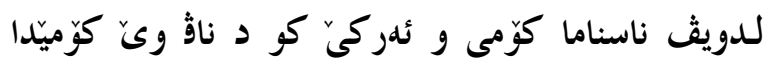

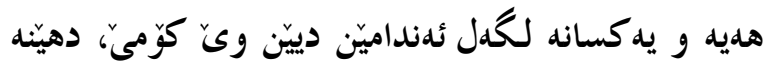
نيشانددان. دشيّت للدويث روّل يان كاريّ كو ئهن ئنام دودت بهيّته بِّلينكرن (ماموّستان

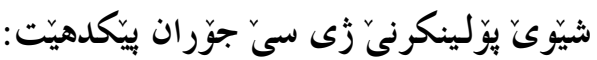

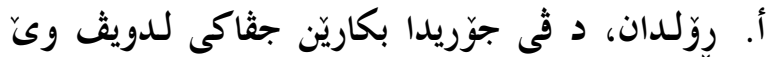
جالاكيا ئلنجام ددهن، دهيّته نيشاندان. وهكى: باريّزهر،

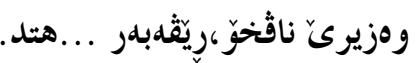

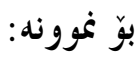

2. (تاقميّك له ناو حيزبى شيوعى دا هلر لـه

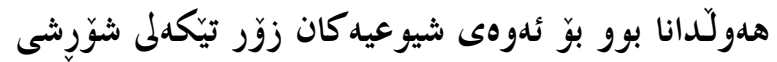

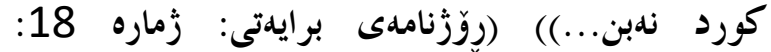
بهريهرى 7) (نههاتيه دياركرن كا ئهو تاقم و ريّباز كيز كن. (به ) دهستنيشانكرن ب بحدند شيّر ان دهيّته ئنجامدان:

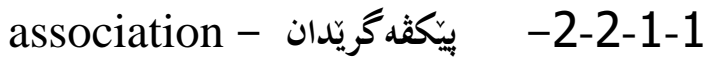

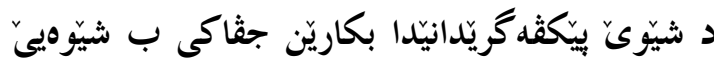

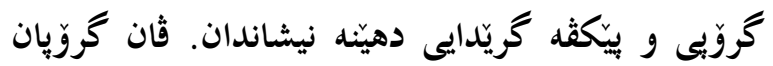

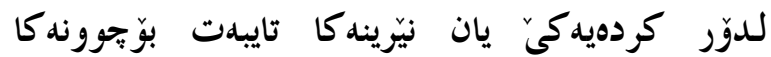

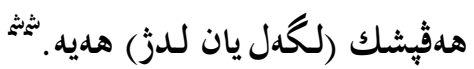

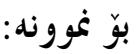

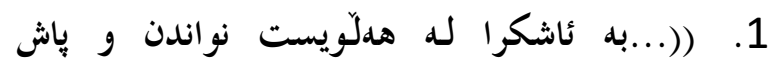

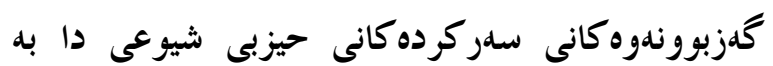
ئاشكرا جحهندان جار دهركهوتوه هدتا بلمرامبهر بله

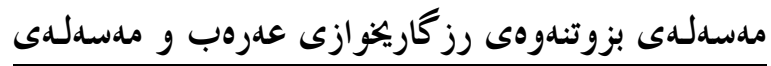

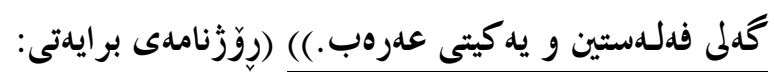
زماره 15: بلمريهرين 7) 2. (ائدوهبوو ديكتاتوريتى تاك رهوى قاسم كهوته دهست دريّزى بوّ سهر بزووتنهوهى نيشتمانى كورد و و دزى هلموو شتيّكى ديمو كراتيانه له عيراقدا و ئهو

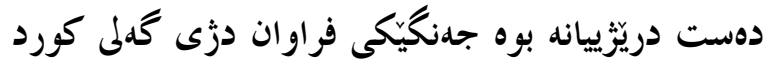

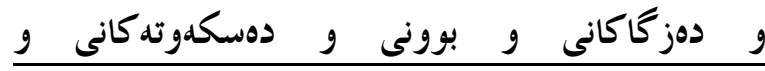

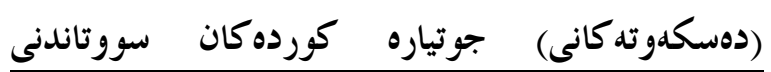

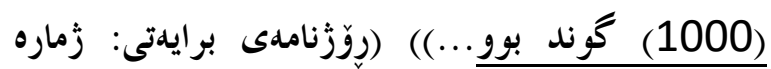
16: بلهريهرى 7 (16)

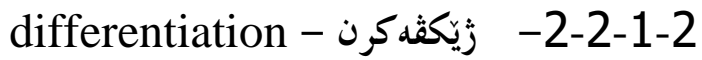

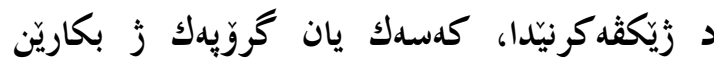

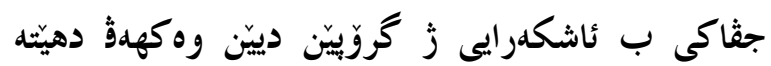
و self - جوادكرن و ب دهبرينهكا دى خوهيى نdخوهيى - other بلهيدا دبيت.

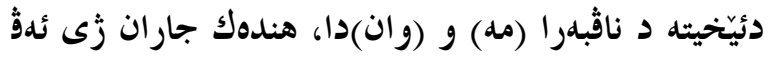




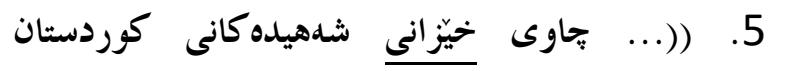

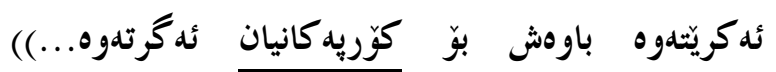

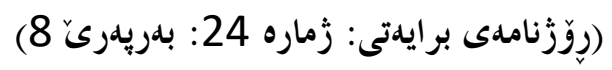

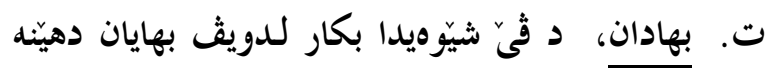

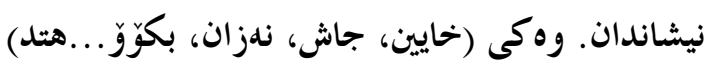

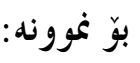

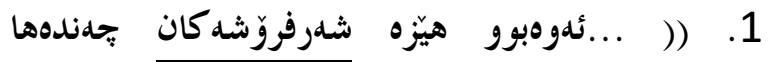

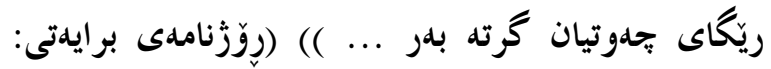

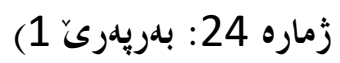

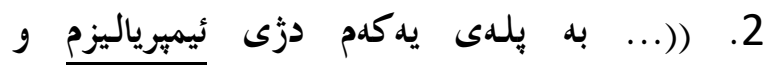

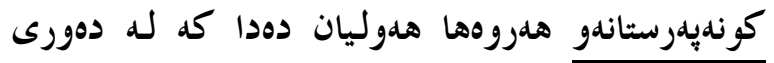

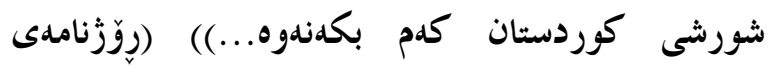

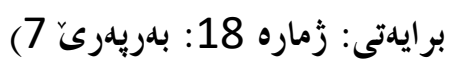

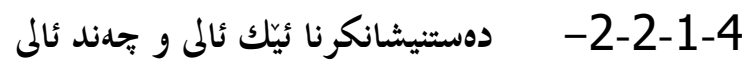
د دهستنيشانكرنا ئيّك ئاليدا، بكارى جثاكى د دئك

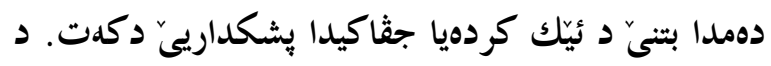

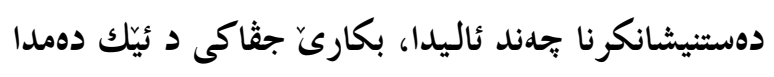

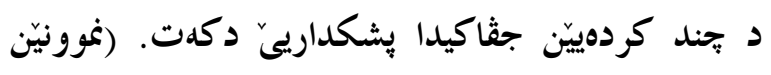

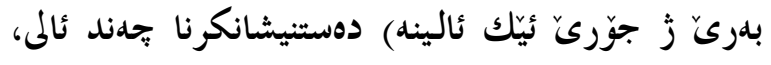

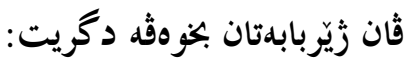
أ. دوووئلى، دوو رِوّليّن هلمبهرى ددهته بكارى، رِّولهك

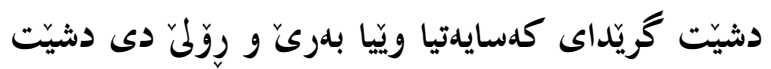
كريّداى كهدايدتيا نو كه و بهيَت بيت.

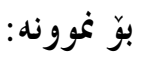

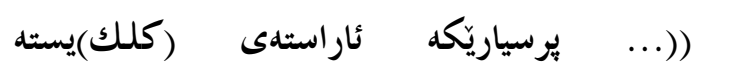

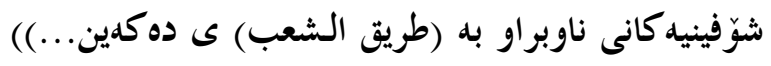

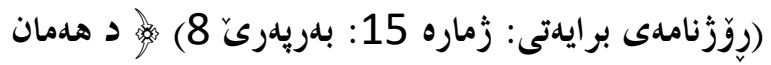
دهمدا كو سهر ب حيزبا شيوعيا عيراقينه، دويثهلانكيّن شَّفينيانه زَى. ب. هيّماكرن، بكارهينانا فَى شيّوهى ل وىى دهميه كو ل شوينا بكاريّن راستهقينه د كردهيِّن جثاكييّن بلرهبلاقدا،

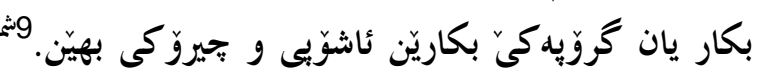

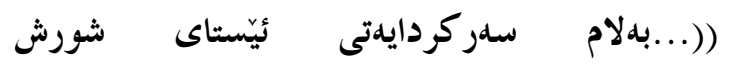

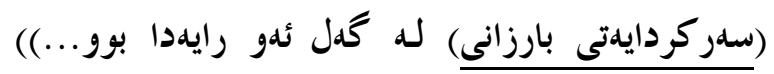

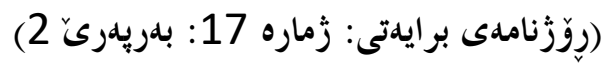

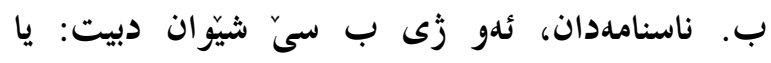

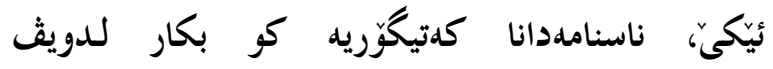

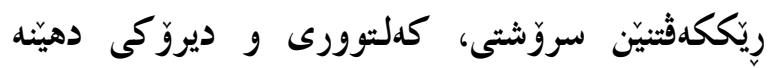
يِيناسهكرن، وهكى نهزاد، ندتهوه، نفش، ئايين، يبشه،

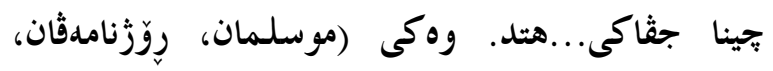
كافر، ندتهوهيهرست و...هتد) يا دوويىّ، ناسنامهدانا

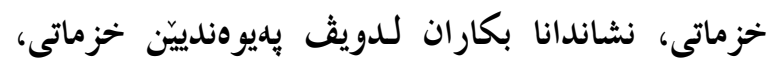
هdثالينى و بيشهيى دبيت. وهكى، هلمى براييّن مله،

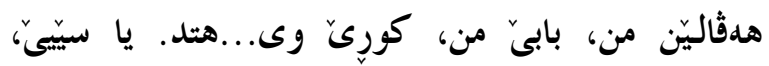

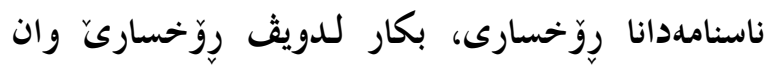

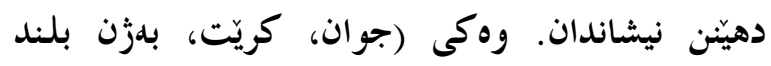
و....هتد)

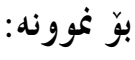

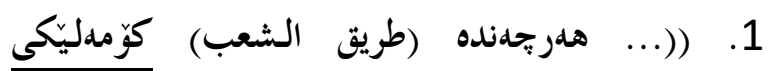

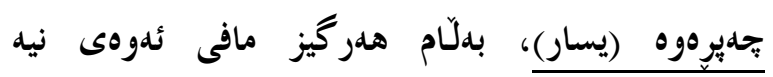

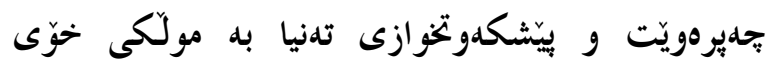

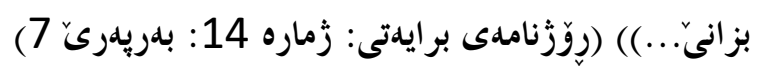

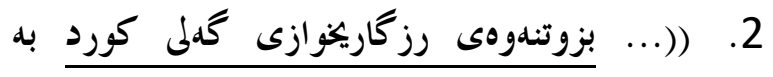
روونى، بوويجدلّى ئهو هلّوّيستانهى (طريق الشعب) يان

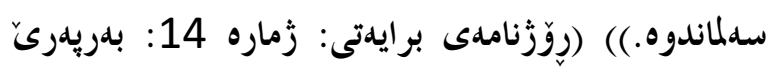

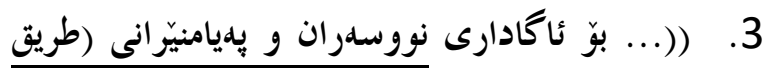
الشعب) و بوّ ئهوهى شويّن و جيّى خحّيان بزانن،...))

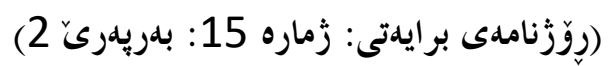

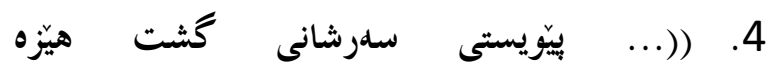

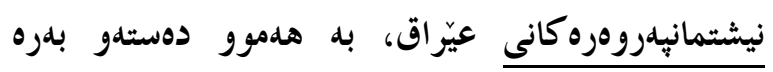

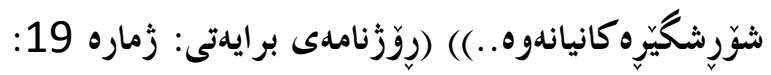

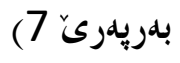


3. () له لايه كموه ئدم تاقمه هدلبازه هدليهيةكى روى

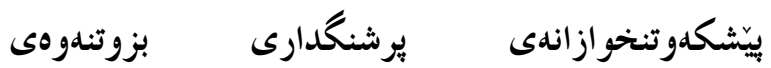

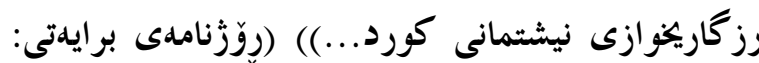

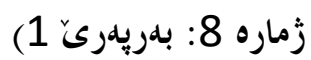
2. بdرجستهكرن - Objectivation

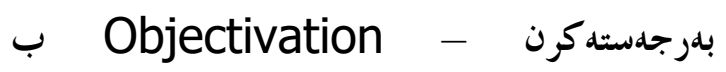
ئارمانجه كا جوداتر دهيّته ئلنجامادن، هندهك جاران بوّ

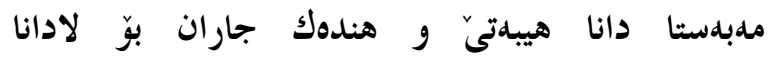

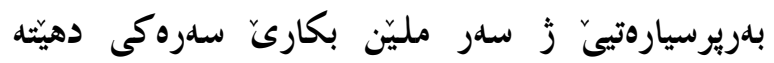

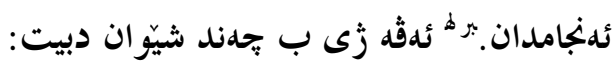

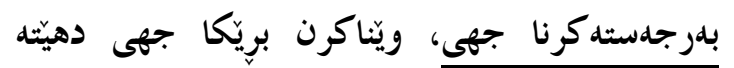

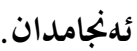

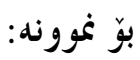
1. ()... هلر له كوردستاندا نهك لـه بهشه كانى ترى

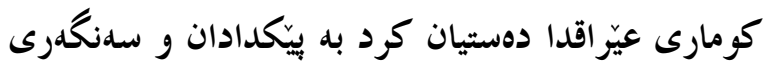

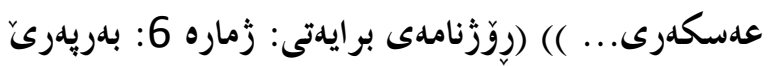

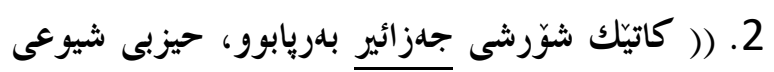

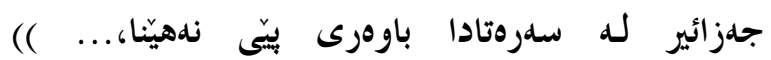

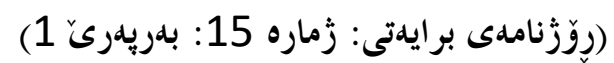

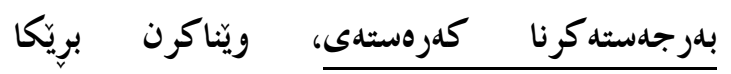
كهرهستهى دهيّته ئدنجامدان.

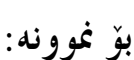

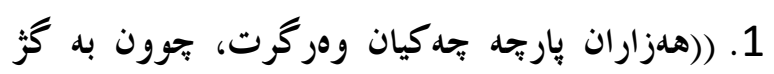

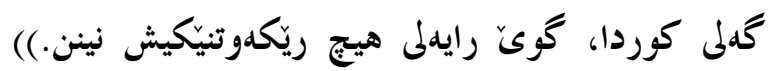

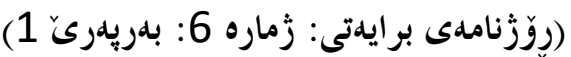

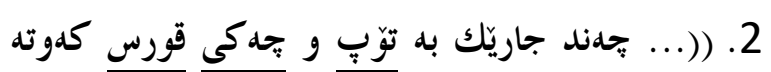

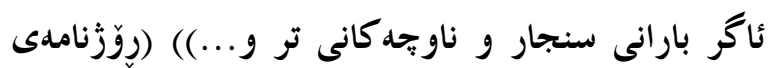

$$
\text { برايدتى: زماره 6: بلريهرى 1) }
$$

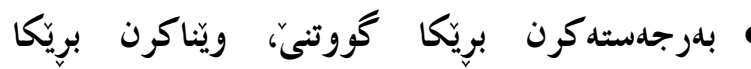

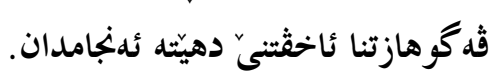

$$
\text { بوّ نموونه }
$$

بكارهينانا شيرين و فهرهاد، مهم و زين، كاوى ناسنكهر، زهحاك و....هتد.

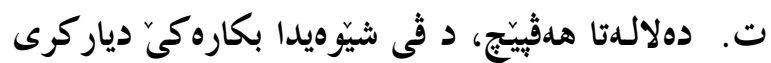

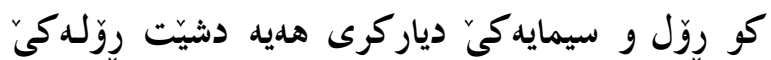
دى زى وهربخريت.

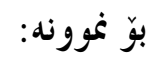

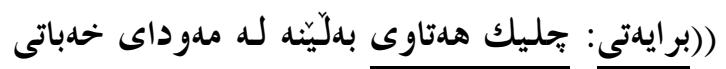

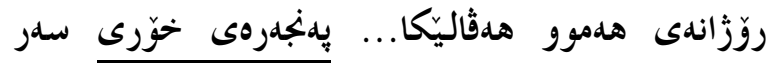
باخجهى بهرى رهنجى بر فيداكارى هلمور روّلهه

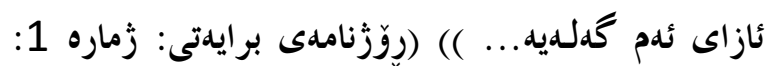

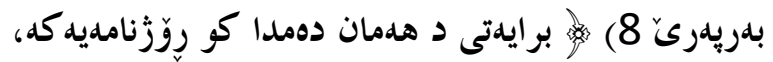
تيشكا روّزَى و يهنجهره و هدتاثه زئ.

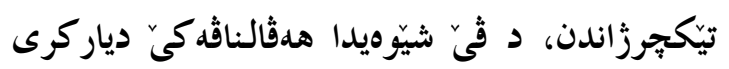

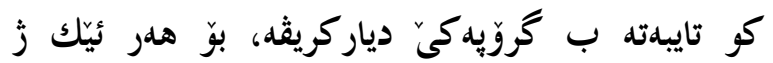
ئهنداميّن وى گرَّبى دهيّته بكارهينان.

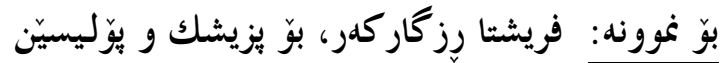
ئاكر قدمر اندنى دهيّنه بكارهينان.

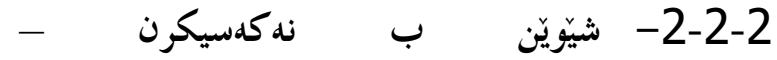
impersonalization ب دوو شيَوان دبيت:

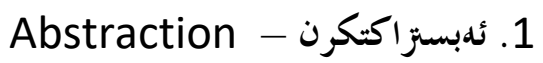

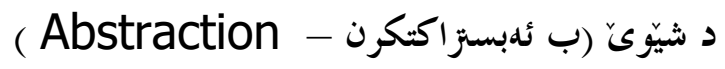

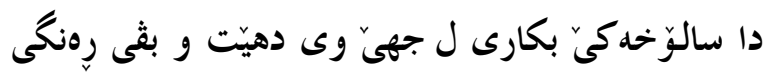

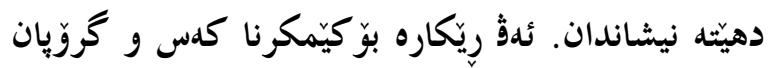

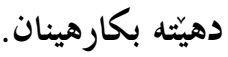

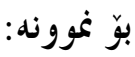

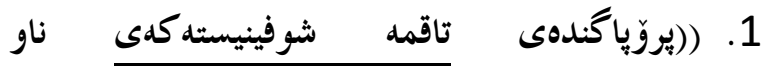

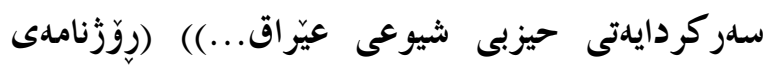
برايلتى: زماره 13: بهريهريى 5)

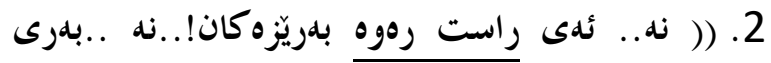

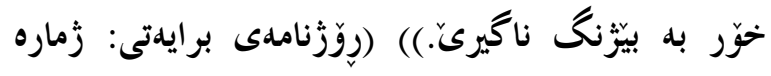

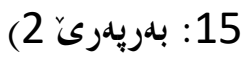




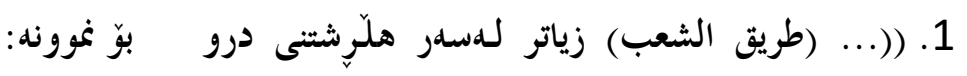

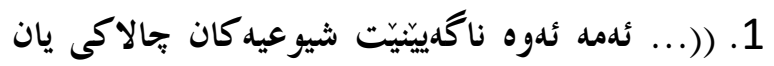

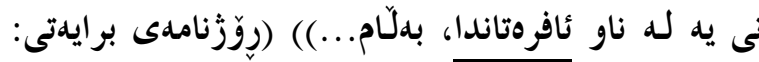
زماره 15: بلمريهرين 2)

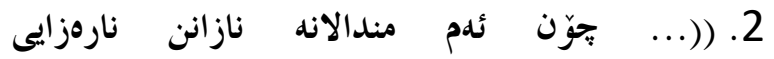

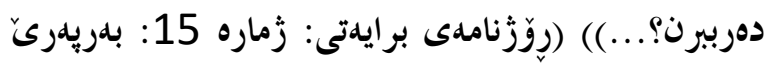

تاك لِيّزرين، بلدرخحان بهُ، بارزانى، ئيزّدين شاه

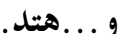

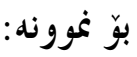

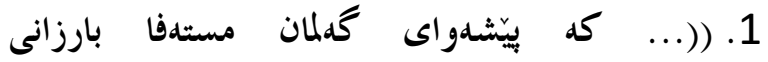
سهركردايدتى دهكات...) (روّزَناملى برايدتى: زماره

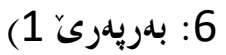

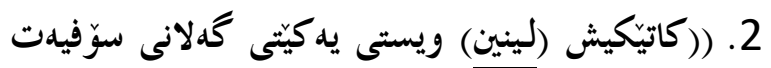

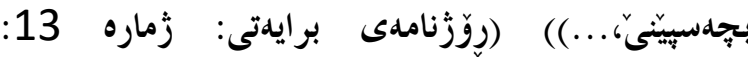

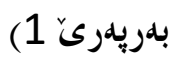

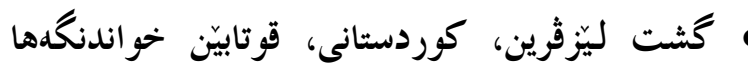
نوى، زاناييّن ئاينى، زاناييِن كورد....هتد.

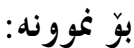

1. ((جهماهيرى كوردستان بلهردهوامه ل ل دهربرينى

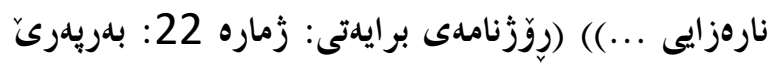

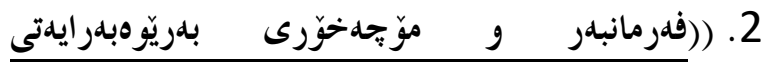
يِهروهردهى دهوك به توندى نارهزايى خوّيان بهرامبهر درو و دهلهسه كانى - طريق الشعب - دهردهبرن...())

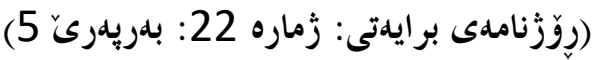

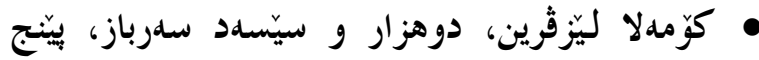
هزار زن و زاروّك و ....هتد.

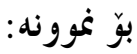
1. (20 بحهد كدارى شيوعى كمرانهوه باوهشى شورشه

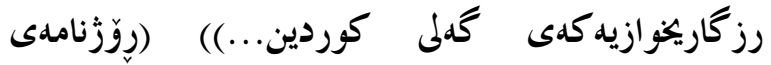
برايدتى: زماره 22: بلريهرى

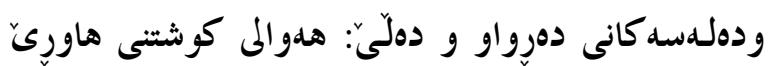

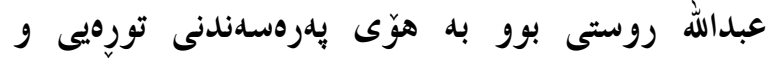

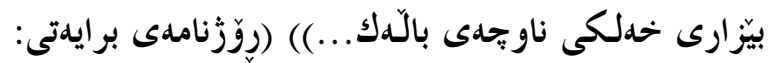

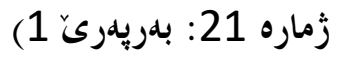

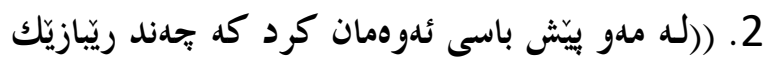
له ناو حيزبى شيوعى عيّراقدا هليه...) (رِوَّزنامهى برايدتى: زماره 16: بلريهرى 1 1)

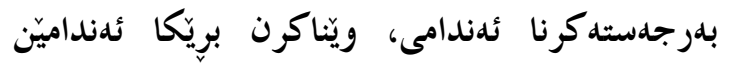

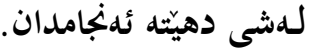

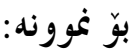

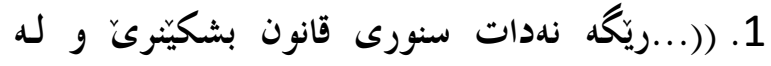
هdموو كهديّك بدات كه نيازيّكى واى له دلا بيّت...())

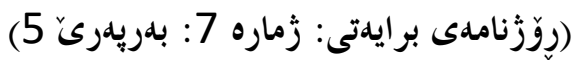
2. ((داوايان لمّ دهكدين با نوينهرانى خوّيان بوّ

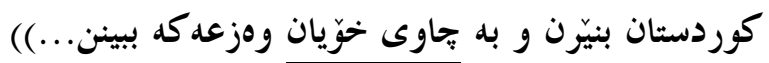

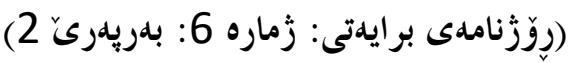

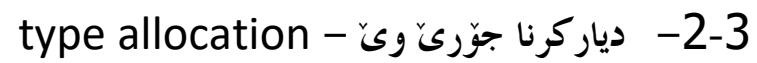

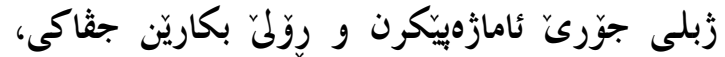

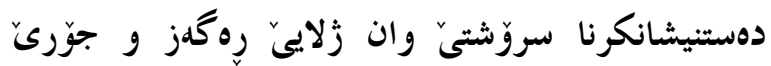

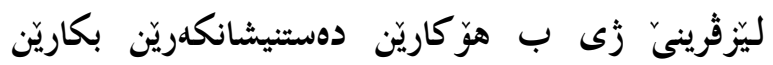

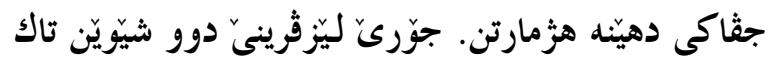

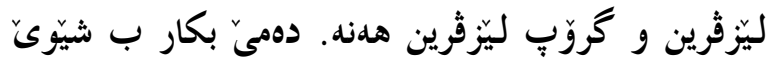

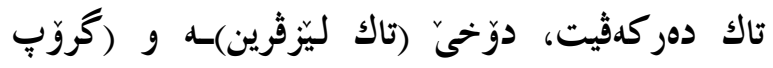

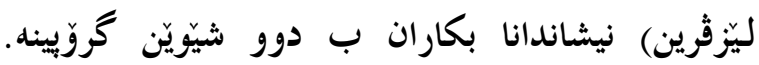

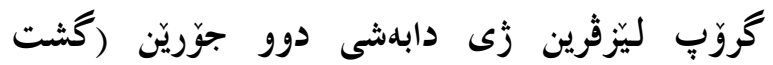

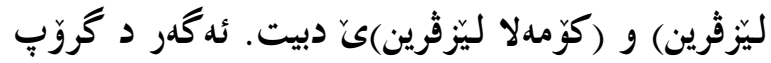

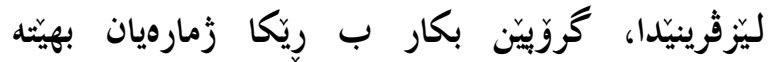

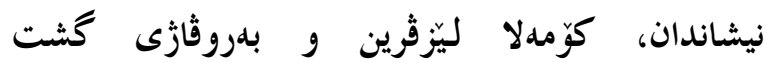

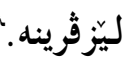

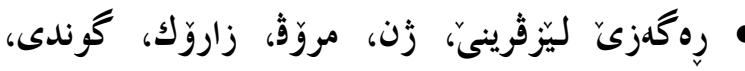

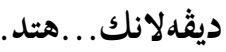




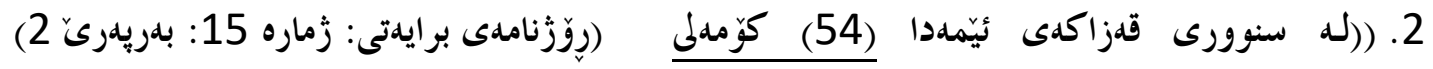

$$
\begin{aligned}
& \text { جوتيارى }
\end{aligned}
$$

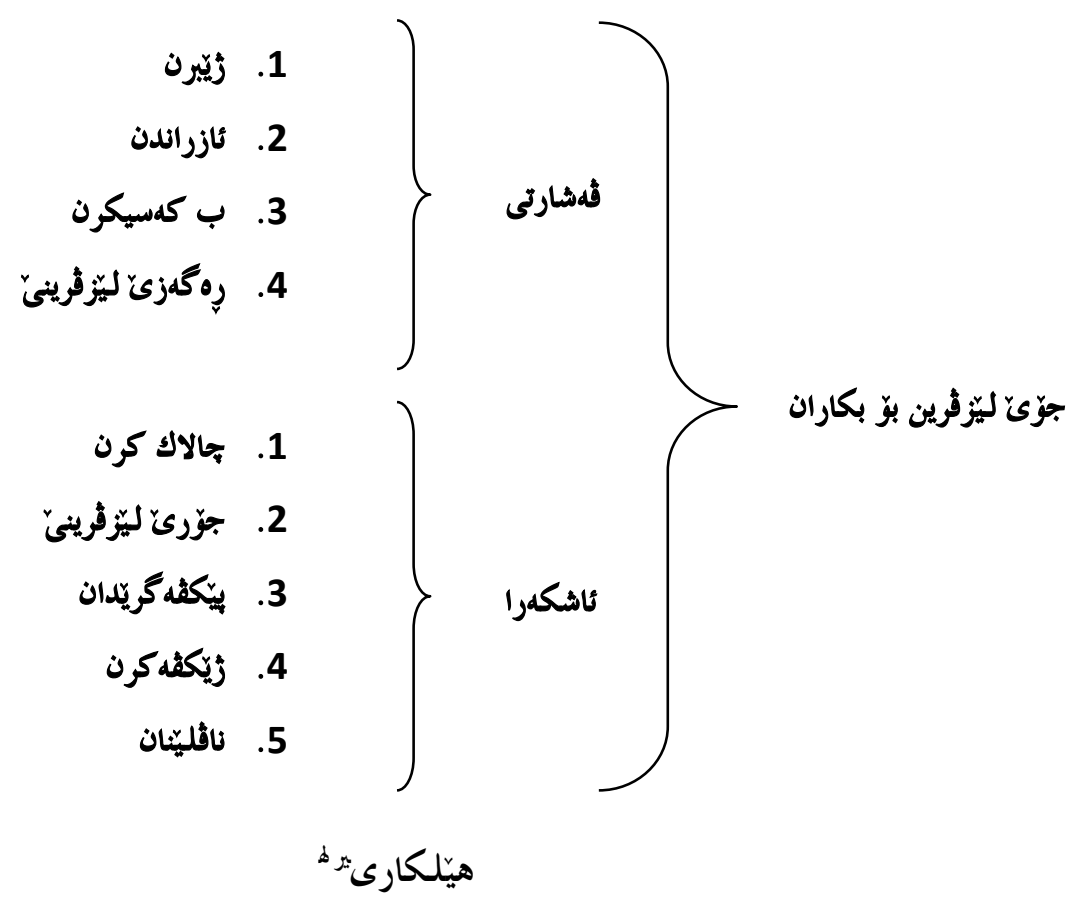

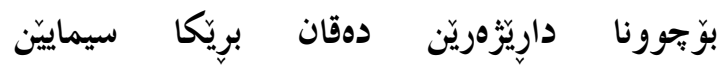

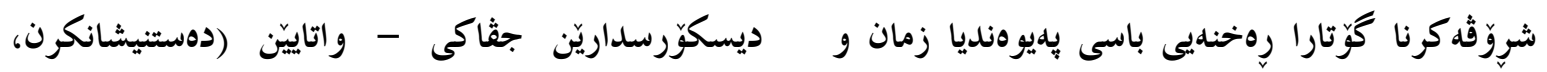

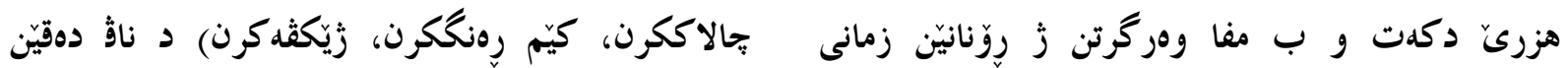

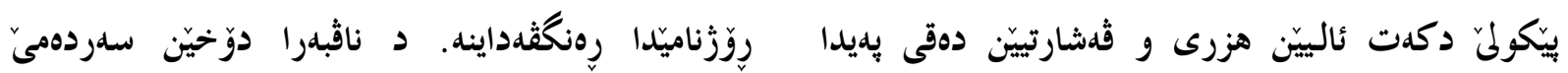

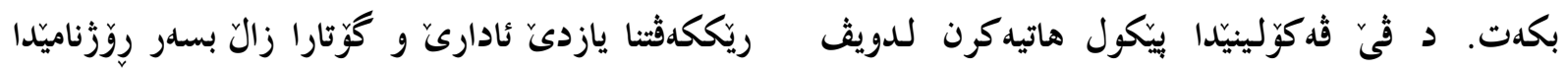

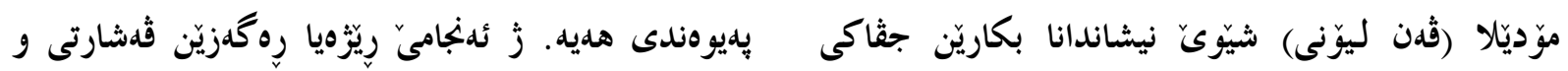

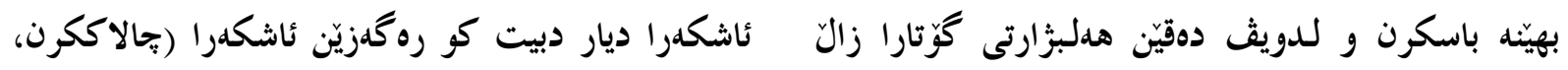

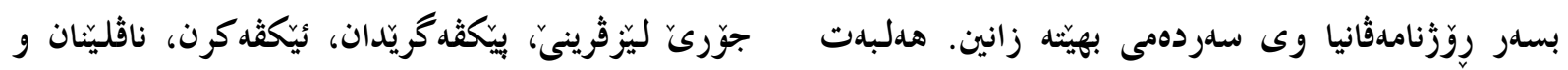

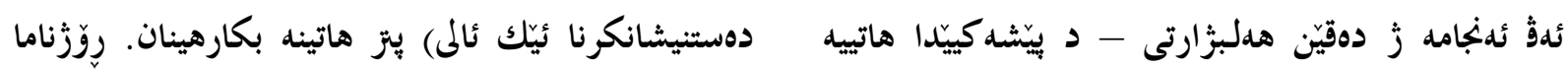

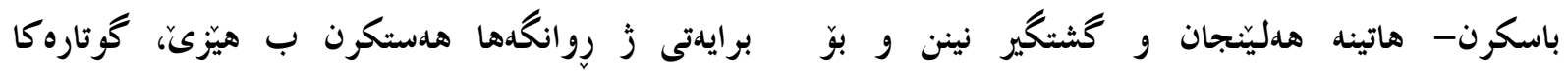

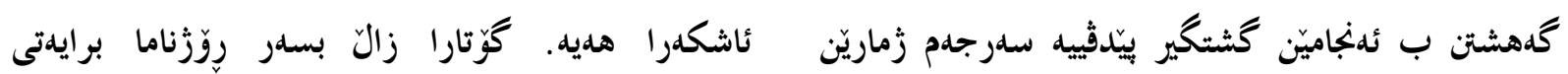

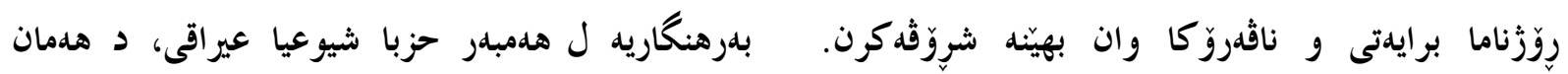

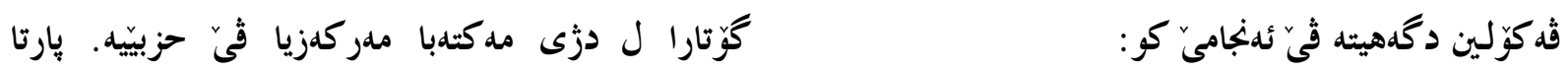

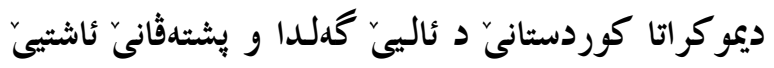


27. محمد مهدى فرقانى و سيد جمال الدين اكبرزاده جهرمى: $135: 1390$ 28. 29. سيامك صاحبى و محمد هادى فلاحى: 1389: 136 : 135: 116.

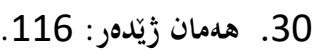

31. سيامك صاحبى و محمد هادى فلاحى: 1389: 117

32. فردوس اقاكل زاده، رجا خير ابادى: 1392: 5. 33. سيامك صاحبى و محمد هادى فلاحى: 1389: 117.

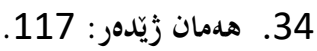

Carmen Rosa Caldas-Coulthard and .35 Malcolm Coulthard: 2003: 39 .83: 1393: 36 سميه زمانى :39

Carmen Rosa Caldas-Coulthard and .37

Malcolm Coulthard: 2003: 39 .83: 1393: 38 سميه زمانى

Carmen Rosa Caldas-Coulthard and .39 .Malcolm Coulthard: 2003: 39 40. ليلا حق يرست: 1391 :54. 41. لطف اله يارمحمدى ...: 1389: 151. 42. يهلوان نزا و و ديكران:1388 : 57-58.

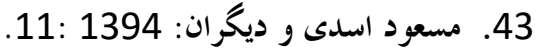

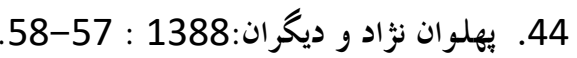
45. هلمان زَيْدرد: 57-58.

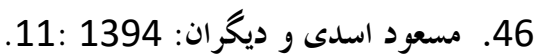
47. اتنا يوشه: 1392: 120.

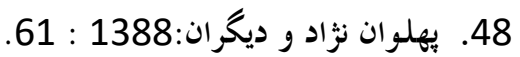
49. هلمان زَّيّدر: 62. 50. 50

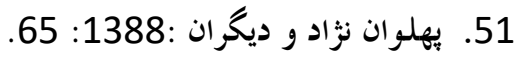

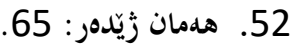
زئدهر: 1. اتنا يوشنه و مرتضى بابك معين، تحليل كفثمان در اثرى از

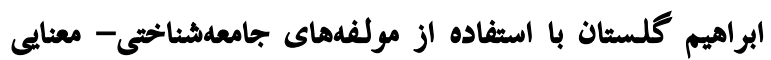
كفتمان مدار با توجه به بازنمايى كارگزاران اجتماعي، دو ماهنامه جستارهاى زبانى، دوره (4)، شماره 2 (بيابى 14 14)، تابستان .1392

2. حمزه نوذرى، غلامرضا :مشيديها و ديكران، سودمندى

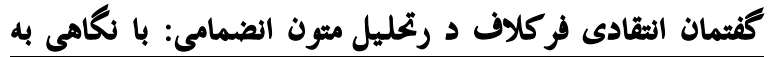
متون توليد شده رسانهاى با محوريت بحران اتصادى و اجتماعى

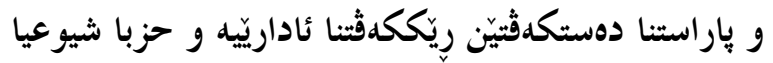

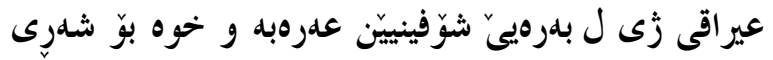

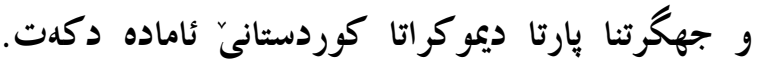

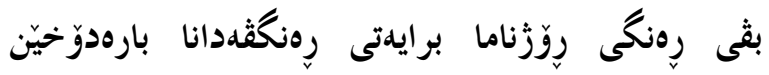
سياسى و جثاكييّن سهردهميّن خوهيه.

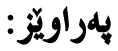
1. مريم مظفرى بور، سيد محمد على تقوى و ديخران:1389 64:

2. علبدولسهلام نهمهدين علبدوللا شيّرزاد سهبرى على:2011. 3. محمد جواد محسنى: 1391: 64.

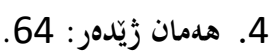

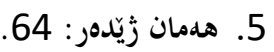

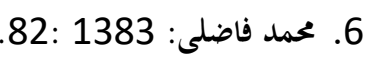
7. فركلاف: 1389: 97-98. 8. 82: 9. محمد جو اد محسنى: 1391: 65.

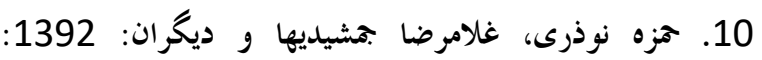
.157

11. محمد فاضلى:1383.83-82:

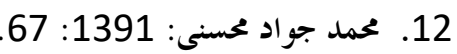
13. فردوس اقاگل زاده: 1386: 20.

14. محمد جواد محسنى: 1391: 1397.

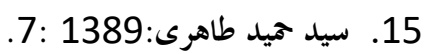
16. فردوس اقاكل زاده، رضا خيز ابادى و ديكران:1391 .30:

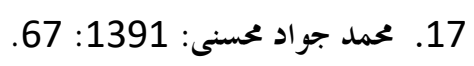
18. 18 19. داود دعاكويان:1387 : 1387. 20. فواد ايزدى و حكيمه سقاى بى ريا:1387 : 109.

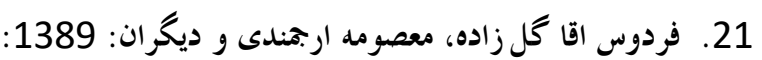

22. 20 : محمود جنيدى جعفرى : 1394

23. محمد رجا يهلوان نزاد: 1388: 52.

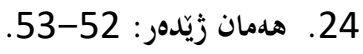
25. هلمان زَيْدهر: 52. 26. سيد على قاسم زاده و مصكفى گر جى: 1390: 32 : 32 
12. فواد ايزدى و حكيمه سقاى بى ريا و ديكران، تحليل

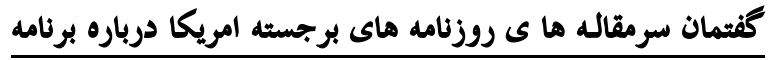

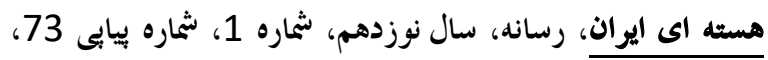
بهار 1387.

محمد جواد محسنى، جستارى در نظريه و روش تحليل .13

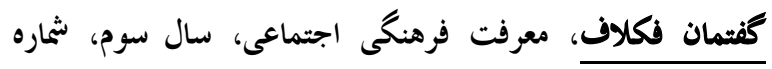

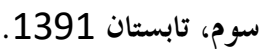
14. محمود جنيدى جعفرى، بررسى بازنغايى كنش هاى اجتماعى نائ

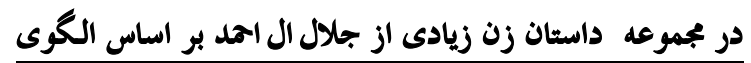

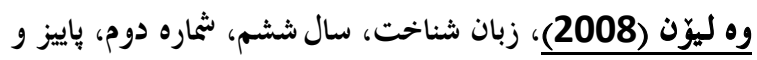
زمستان، 1394.

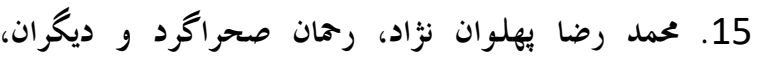

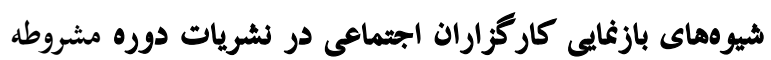

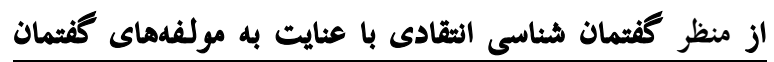

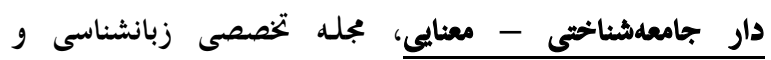
كويشهاى خراسان دانشكده ادبيات و علوم انسانى مشهد علمى يزوهشى، شماره1، باييز و زمستان 1388.

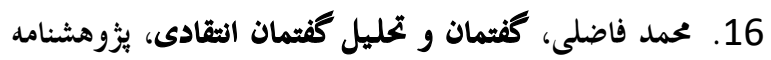

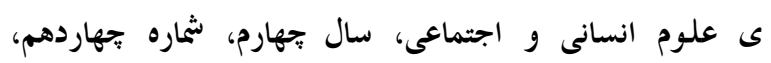
.1383

17. محمد مهدى فرقانى و سيد جمال الدين اكبرزاده جهرمى،

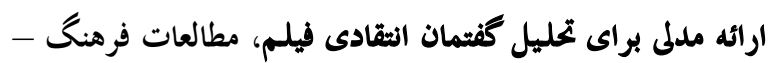
ارتباطات، سال دوازدهم، شماره شانز دهم، زمستان 1390. 18. مريم مظفرى بور، سيد محمد على تقوى و ديكران، تحليل

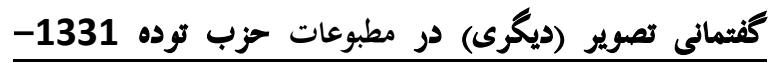

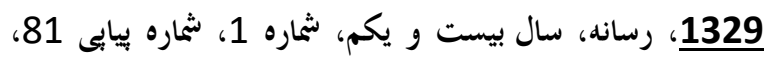

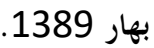

19. نورمن فركلاف، تحليل انقادى گفثمان، گروه تربمه:

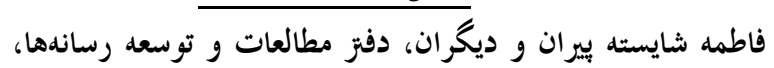

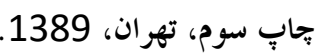

20. Carmen Rosa Caldas-Coulthard and Malcolm Coulthard, Texts and PracticesReadings in Critical Discourse Analysis, London and New York. 2003.
اخيز اروبا و امريكا، مطالعات و تحقيقات اجتماعى در ايران، دوره دوم، شماره 1، بهار 1392.

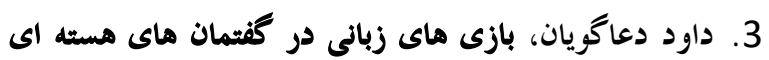

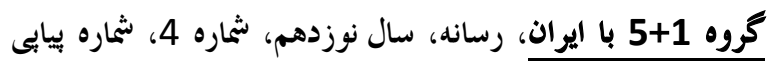
76، زمستان 1387. 138

4. سيامك صاحبى و محمد هادى فلاحى و ديكران، بران، بررسى و

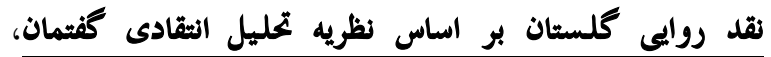
يُروهش زبان و ادبيات فارسى، شماره 16، بهار 1389.

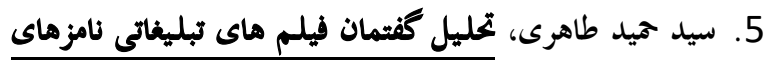
دممين دوره انتخابات رياست جمهورى اسلامى ايران - 1388، دانشكده صدا و سيما بمهورى اسلامى ايران، بِايان نامه دوره

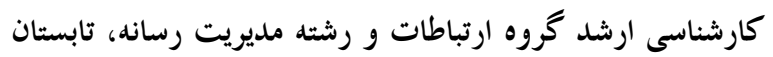
.1389

6. سيد على قاسم زاده و مصطفى گرجى، تحليل گفثمان انتقادى رمان دكر نون زنش را بيشر از مصدق دوست داده داهت، ادب يزوهى، شماره 17، باييز 1390.

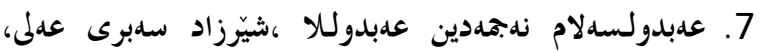
زماثفانييا تيوزرى، سبيزيّز، دهوك، 2011.

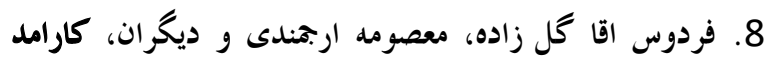

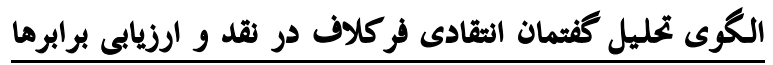
در متون ترجمه شده (خواهران) اير جيمز جويس، فصلنامه يثزوش هاى زبان و ادبيات تطبيقى، دوره 1، شكاره 3،ياييز .1389 9. فردوس اقاگل زاده، تحليل كفتمان انثقادى و ادبيات، ادب يثوهى، شماره اول بهار 1386.

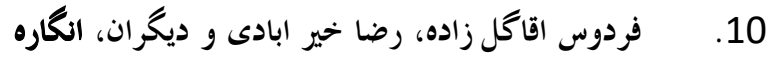
زبان شناختى نظارش و كزينش خبر: رويكرد تحليل كفتمان

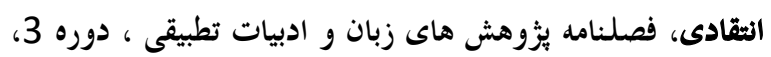
شماره4، بيابى 12، زمستان فئامل بروهش هاى زبان 1391. 11. فردوس اقاكل زاده، رضا خير ابادى و ديخر ان، مطالعه تطييقى بازنمايى كنشكران ايرانى و غربى د يرونده مستهاى ايران

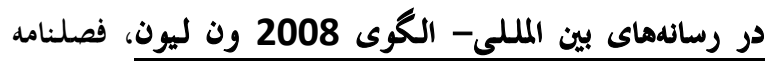
جستارهاى زبانى، دوره 4، شماره 1، بيابى 13، بهار لانس 1392. 


$$
\text { تحليل الحطاب النقدي في جريدة برايتى (وفق المكون الاجتماعي-معاني فن ليون) }
$$

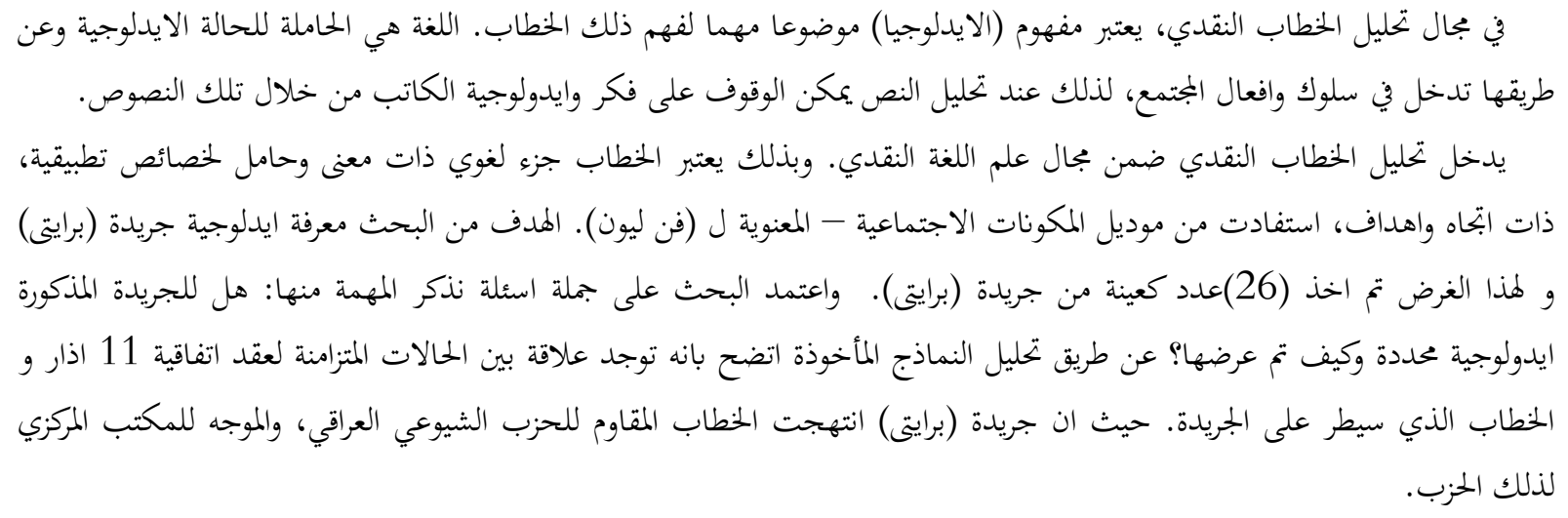

\title{
CRITICAL DISCOURSE ANALYSIS OF BRAYATI NEWSPAPER BASED ON SOCIOLOGICAL COMPONENTS -VAN LEEUWEN'S SEMANTICS
}

\begin{abstract}
:
The concept of Discourse for its understanding is to be considered as an important topic In terms of Critical discourse analysis. Language is the holder of Ideology; ideology is embodied in behaviors and social practice by the help of Language. Therefore, we could identify the idea and ideology and of these writers' texts through analyzing the given texts.

Critical Discourse analysis is related to the linguistics criticism field. To highlight this point that the discourse is a meaningful part of language and it is the holder of targeting characteristics. The advantages are taken from the Van Leeuwen's Semantics and Essential style of Sociology. The aims of this study is knowing the Brayati Newspaper's Ideology, and for this purpose, (26) Volumes of Brayati Newspaper are taken. The important questions of this study are to know whether the newspaper has a specified ideology, and how it was indicated. It is to be concluded from the results of the taken samples' analysis that there is a relationship between the conditions of the period during 11th March Treaty and the influential Article on the newspaper. Brayati Newspaper has a clear article in terms of feelings and power. The influential Article on the Brayati newspaper is a challenging against Iraqi Communist Party, it is the same article in which stands against the Central Bureau of that party.
\end{abstract}

